\title{
LEGAL PLURALISM \& WOMEN'S RIGHTS: A STUDY IN POST-COLONIAL TANZANIA
}

\author{
By: Mark J. Calaguas, Cris M. Drost, Edward R. Fluet
}

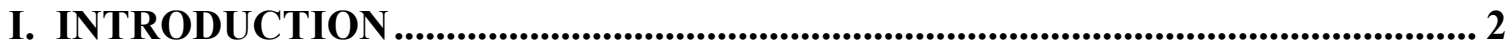

II. LEGAL PLURALISM AND WOMEN'S RIGHTS: AN OVERVIEW ................. 5

III. A BRIEF POLITICAL HISTORY OF TANZANIA ……........................................ 13

IV. DEVELOPMENT OF TANZANIA'S LEGAL SYSTEMS................................... 15

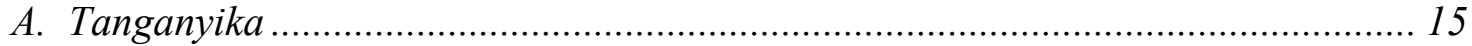

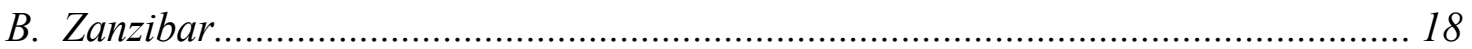

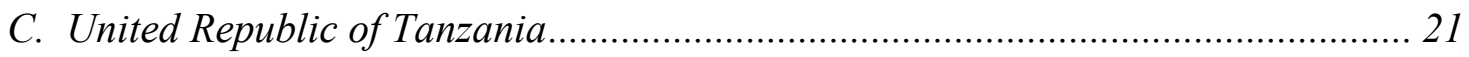

V. THE LAW OF MARRIAGE AND DIVORCE IN TANZANIA .......................... 22

A. Unification of Marriage Law in Tanganyika: The Law of Marriage Act............... 22

1. Key Statutory Provisions ................................................................................. 24

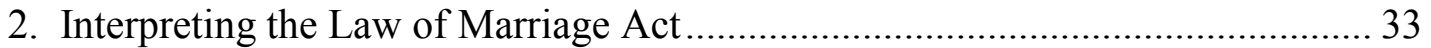

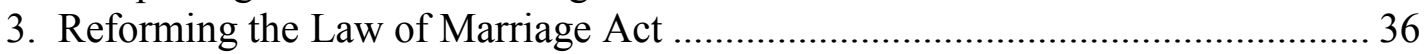

B. The Law of Marriage and Divorce in Zanzibar ................................................. 48

1. The Law of Marriage and Divorce for Muslims in Zanzibar............................... 49

2. The Law of Marriage and Divorce for Non-Muslims in Zanzibar ....................... 61

3. Special Provisions for Unwed Mothers and Nonmarital Children .................... 64

VI. RESPONDING TO LEGAL PLURALISM........................................................... 65

A. The "Transformative Accommodation" Model of Joint Governance ..................... 68

B. Joint Governance, Legal Pluralism, and the Tanzanian Experience ...................... 70

C. Challenges and Opportunities for Reform in Tanzania ...................................... 77

VII. CONCLUSION ............................................................................................................. 83 


\section{INTRODUCTION}

Shindano is a sixty-year-old woman who lives on the island of Zanzibar, a semiautonomous region of Tanzania. ${ }^{1}$ She has been residing in the small village of Mkokotoni, where she has had to survive without support from her husband, Abu, for the last five months. After five years of marriage, Abu ordered Shindano out of his home, telling her to "leave [his] house and go back to be with [her] fellow dogs, slatterns, and lunatics." While Abu initially supported her for a few months, he has not helped her financially for some time. Shindano now seeks to dissolve her marriage to Abu in the local kadhi's court, claiming that Abu's statements and actions constitute a divorce under Islamic law. The court denies Shindano's request because Abu never uttered or wrote the appropriate Islamic divorce formula. She is ordered to return to her husband and treat him well; the court orders Abu to support his wife and respect her.

This story is an example of a typical divorce proceeding within the kadhi's court system of Zanzibar. Had Shindano been a man, however, or a non-Muslim, or a resident of mainland Tanzania ("Tanganyika"), the result of this proceeding may have been very different. Courts in Tanganyika and Zanzibar each recognize and enforce the right of Muslim men to unilaterally divorce their wives under Islamic law. Yet, Tanganyika's family law in addition provides for a uniform, secular marriage dissolution process, which is available to both men and women regardless of religious affiliation. In Zanzibar, marriages between Muslims are dissolved solely in accordance with principles of Islamic law, while non-Muslims do not have any official statutes to govern their divorce proceedings.

\footnotetext{
${ }^{1}$ Erin Elizabeth Stiles, A Kadhi and His Court: Marriage, Divorce, and Zanzibar's Islamic Legal Tradition 288 (Aug. 2002) (unpublished Ph.D. dissertation, Washington University) (on file with John M. Olin Library, Washington Univ.) [hereinafter Stiles, A Kadhi and His Court].
} 
The United Republic of Tanzania ("the Republic"), a political union of two semiautonomous entities, the mainland area of Tanganyika and the islands of Zanzibar, ${ }^{2}$ is a nation composed of multiple ethnic, religious, and tribal groups. Like most of its African neighbors, Tanzania underwent a period of colonization, during which a series of European nations ruled over both Tanganyika and Zanzibar. These colonizers established a dual system of law - one legal system for the European population and another for the indigenous inhabitants. Following independence, Tanzania and its neighbors on the continent sought to shed this discriminatory form of justice and establish a system that represented and respected the culture of its people. Because the borders drawn by European colonial powers were virtually arbitrary in nature, many of the newlyindependent states that succeeded those former colonies also inherited the same political boundaries. As a result, countries such as Tanzania are populated by a heterogeneous citizenry, the members of which belong to any number of ethnic, racial, religious, and tribal communities.

This article examines the problems that arise when multicultural societies adopt a pluralist system of justice in order to preserve the traditions of its diverse communities, using Tanzania as a case study. The authors illustrate that despite Tanzania's considerable efforts in balancing individual and group rights, its political leaders have replaced the nation's colonial legal system with one that is still fragmented and discriminatory. In order to accommodate its various religious and ethnic groups, Tanzania established a pluralistic legal system that while laudable in its objectives, denies some of its citizens the basic equal protection guarantees provided in the Tanzanian

\footnotetext{
${ }^{2}$ Kenneth McK. Norrie, Administration of Justice in Tanzania and Zanzibar: A Comparison of Two Judicial Systems in One Country, 38 INT’L \& COMP. L.Q. 395 (1989).
} 
Constitution and under international law. This problem is especially symptomatic in family law, a sensitive area that implicates the most sacrosanct of personal relations and delineates the outermost boundaries of community membership. As evidenced by the laws of marriage and divorce currently in force, Tanzania affords its citizens radically different rights based on their gender, religion, and place of origin. While Tanzanian matrimonial law represents a relatively narrow field of academic inquiry, the lessons drawn from an investigation into this legal and cultural milieu can be illuminating when placed within the context of larger issues affecting multicultural societies. The so-called "paradox of multicultural vulnerability" ${ }^{3}$ affects not only young, postcolonial nations in Africa ${ }^{4}$ and $\mathrm{Asia}^{5}$, but also individuals in cosmopolitan, economically-developed countries such as Israel, ${ }^{6}$ the United States, ${ }^{7}$ and Canada. ${ }^{8}$

\footnotetext{
${ }^{3}$ Ayelet Shachar, Multicultural JuRisDictions: CUltural DifFERENCES AND Women's Rights 3 (2001) [hereinafter SHACHAR, MULTICULTURAL JURISDICTIONS].

${ }^{4}$ See, e.g., Boaventura de Sousa Santos, The Heterogenous State and Legal Pluralism in Mozambique, 40 LAW \& SOC'Y REV. 39 (2006); Aili Mari Tripp, The Politics of Women's Rights and Cultural Diversity in Uganda, in GENDER Justice, DEVElopMENT, AND Rights 427-32 (Maxine Molyneux \& Shahrashoub Razavi, eds., 2002); Anne Hellum, Human Rights and Gender Relations in Postcolonial Africa: Options and Limits for the Subjects of Legal Pluralism, 25 LAW \& SOC. INQUIRY 635 (2000); David M. Bigge \& Amelie von Briesen, Note, Conflict in the Zimbabwean Courts: Women's Rights and Indigenous SelfDetermination in Magaya v. Magaya, 13 HARV. HUM. RTS. J. 289 (2000); Anne Griffiths, Reconfiguring Law: An Ethnographic Perspective from Botswana, 23 LAW \& Soc. INQUIRY 587 (1998).

${ }^{5}$ See, e.g., Pratibha Jain, Balancing Minority Rights and Gender Justice: The Impact of Protecting Multiculturalism on Women's Rights in India, 23 BERKELEY J. INT'L L. 20 (2005).

${ }^{6}$ See id. at 57-60 (discussing the plight of the agunah, a woman who is "anchored" into a marriage under Jewish law by virtue of her husband's refusal to grant a divorce).

${ }^{7}$ See Brenda Oppermann, The Impact of Legal Pluralism on Women's Status: An Examination of Marriage Laws in Egypt, South Africa, and the United States, 17 HASTINGS WoMEN's L.J. 65, $87-90$ (2006); Ayelet Shachar, Group Identity and Women's Rights in Family Law: The Perils of Multicultural Accommodation, 6 J. POL. PHIL. 285, 285 (1998) [hereinafter Shachar, Group Identity and Women's Rights] (citing the U.S. Supreme Court case, Santa Clara Pueblo v. Martinez, 436 U.S. 49 (1978), which declined to interfere with gender-biased qualifications for Native American tribal membership).

${ }^{8}$ In 2003, the Canadian Society of Muslims proposed the establishment of Islamic family law arbitral tribunals in the province of Ontario, a campaign that incited a backlash in the media and in political circles. See generally James Thornback, The Portrayal of Sharia in Ontario, 10 APPEAL 1 (2005). Many of the criticisms related to the potential intricacies involved in reconciling competing bodies of secular and religious law, including "the conflict between the various schools of Islamic law and deciding which one would apply, the conflict between the civil courts applying religious law or instead a separate religious court, and the conflict between certain aspects of Muslim family law and various human rights treaties." Lawrence Blackstone, Courting Islam: Practical Alternatives to a Muslim Family Court in Ontario, 31
} 
Part II of this article describes the phenomenon of legal pluralism and the impact it has on the individual rights of women belonging to communities whose discriminatory cultural practices have been accommodated by the state. ${ }^{9}$ Part III narrows in on Tanzania by offering a brief political history of the nation, ${ }^{10}$ while Part IV describes the development of Tanzania's multifaceted legal system. ${ }^{11}$ Part V surveys the current law of marriage and divorce in Tanzania, highlighting the differentiated nature of justice available to parties in both Tanganyika and Zanzibar. ${ }^{12}$ Part VI then explores ways to alleviate the discrimination written into Tanzania's marriage and divorce laws while acknowledging the significant obstacles that hinder programs for reform in Tanzania. ${ }^{13}$

\section{LEGAL PLURALISM AND WOMEN'S RIGHTS: AN OVERVIEW}

Like many countries that lived through the colonial experience, Tanzania inherited a "legal stew" of European laws superimposed upon or existing concurrently with indigenous systems of customary and religious law. ${ }^{14}$ This phenomenon, which is known as "legal pluralism," has given rise to a field of academic inquiry devoted to the study of how multiple sets of norms, both formal and informal, interact with each other and affect their subjects. ${ }^{15}$ For purposes of this article, the investigation will be limited to the "juristic" view of legal pluralism, which refers to the situation where "the sovereign

\footnotetext{
BROOKLYN J. INT’L L. 207, 218 (2005). The provincial legislature ultimately responded in February 2006 by banning binding arbitration based on religion in the resolution of family law disputes. Kelly Gillespie, 'One law for all Ontarians' in divorce, child custody, TORONTO STAR, Feb. 16, 2006, at A5. For a historically-grounded analysis of the rhetoric behind the sharia debate in Ontario, see Anver M. Emon, Islamic Law and the Canadian Mosaic: Politics, Jurisprudence, and Multicultural Accommodation, SING. J. LEGAL STUD., (forthcoming 2006), available at http://ssrn.com/abstract=898924.

${ }^{9}$ See Infra, Part II.

${ }^{10}$ See Infra, Part III.

${ }^{11}$ See Infra, Part IV.

${ }^{12}$ See Infra, Part V.

${ }^{13}$ See Infra, Part VI.

${ }^{14}$ Jennifer L. Rakstad et al., The Progress of Tanzanian Women in the Law: Women in Legal Education, Legal Employment and Legal Reform, 10 S. CAL. REV. L. \& WOMEN'S STUD. 35, 92 (2000).

${ }^{15}$ Grant R. Woodman, Legal Pluralism and the Search for Justice, 40 J. AFR. L. 152, 157-158 (1996).
} 
commands different bodies of law for different groups of the population varying by ethnicity, religion, nationality, or geography, and when the parallel legal regimes are all dependent on the state legal system."16

Not surprisingly, the legal pluralist paradigm has been criticized for a number reasons, chiefly stemming from its reputation as being "unnecessarily complex, as denying the principle of equality before the law, as underpinning grossly unjust modes of production or racial discrimination." ${ }^{17}$ The argument for applying simpler rules of law springs from the idea that justice is not easily achieved if its administration is too complicated. ${ }^{18}$ Perhaps even more troublesome is the issue of equality before the law. Tanzania's pluralist legal system, which is the main focus of this article, is a prime example of multicultural accommodation, wherein the state "attempts to facilitate groups' practices and norms, for example, by exempting group members from certain laws, or by

\footnotetext{
${ }^{16}$ Sally Engle Merry, Legal Pluralism, 22 LAW \& SoC'Y. REV. 869, 871 (1988). Legal pluralism has also come to describe an anthropologically-oriented study of competing normative systems. This broader conception, called "deep legal pluralism" by Gordon Woodman, extends the concept of "law" to include non-state modes of social ordering. Indeed, the juristic view of legal pluralism, or "state law pluralism," "has sometimes been said not to be true legal pluralism, or at least not to be a form of legal pluralism which can be of interest social science." Woodman, supra note 15, at 158. Gunther Teubner sums up the ethos of the deep legal pluralist approach thus:
}

\begin{abstract}
Postmodern jurists love legal pluralism. They do not care about the law of the centralized State with its universalist aspirations. It is the "asphalt law" of the Brasilian favelas, the informal counter-rules of the patchwork of minorities, the quasi-laws of dispersed ethnic, religious, and cultural groups, the disciplinary techniques of "private justice," the plurality of non-State laws in associations, formal organizations, and informal networks where they find the ingredients of postmodernity: the local, the plural, the subversive.
\end{abstract}

Gunther Teubner, The Two Faces of Janus: Rethinking Legal Pluralism, 13 CARDOzO L. REV. 1443, 1443 (1991). See also Dolores A. Donovan \& Getachaw Assefa, Homicide in Ethiopia: Human Rights, Federalism, and Legal Pluralism, 51 AM. J. COMP. L. 505, 542 (2005) (distinguishing between formal and anthropological concepts of legal pluralism).

${ }^{17}$ Woodman, supra note 15 , at 159 .

${ }^{18}$ Id. at 161 . 
awarding identity groups some degree of self-governance."19 As a result, legal pluralism "provides for different norms to be applied to different persons in the same situation. ${ }^{20}$

While it has been pointed out that unequal treatment of individuals does not automatically make a set of laws unjust, ${ }^{21}$ systems that follow a model of multicultural accommodation pose a unique problem, which has been identified by Ayelet Shachar as "the paradox of multicultural vulnerability." 22 In a diverse nation-state, allowing various religious and cultural groups to manage their own affairs in areas like family law increases the autonomy that these populations enjoy. ${ }^{23}$ Indeed, the idea that multicultural accommodation is antithetical to the principles of liberal democracy has eroded in recent years. ${ }^{24}$ Unfortunately, expansion of communal rights can encroach on the individual rights of particular group members who also fall within "traditionally subordinated

\footnotetext{
${ }^{19}$ Shachar, Group Identity and Women's Rights, supra note 7, at 286.

${ }^{20}$ Woodman, supra note 15 , at 160 .

${ }^{21} I d$. at 162 (arguing that no legal system provides for absolute equality under the law).

${ }^{22}$ Shachar, MUlTiCUltural JURISDICTIONS, supra note 3, at 3; see also Shachar, Group Identity and Women's Rights, supra note 7, at 289.

${ }^{23}$ Shachar, Group Identity and Women's Rights, supra note 7, at 289. Family law is an especially crucial arena where the debate over multicultural accommodation plays out because it "demarcates membership boundaries in two related ways: first, by developing complex lineage rules which determine who, by virtue of birth, is eligible for acquiring full membership in the group, and secondly, by defining who by way of marriage can become a group member." SHACHAR, MULTICULTURAL JURISDICTIONS, supra note 3, at 5152.

${ }^{24}$ See generally, e.g., WILL KYMLICKA, LiBERALISM, COMMUNITY, AND CULTURE (1989); IRIS MARION Young, JustiCE AND THE POLITICS OF DifFERENCE (1990); Jürgen Habermas, Address, Multiculturalism and the Liberal State, 47 STAN. L. REV. 849, 850-51 (1995). Theorists have traditionally asserted that liberalism's exaltation of individual autonomy to be in conflict with multiculturalism's preoccupation with securing communal rights. There has been greater recognition, however, that social attachments are "one of the principal ways in which person define themselves," thus leading to the result that "groupdifferentiated rights are now substantially more likely to be defended as essential to individual well-being." Eric J. Mitnick, Individual Vulnerability and Cultural Transformation, 101 MicH. L. REV. 1635, 1636-37, 1640 (2003) (reviewing SHACHAR, MULTICULTURAL JURISDiCTIONS, supra note 3]. Additionally, defenders of multicultural policies have asserted that such measures "help[] to remedy the disadvantages which minorities suffer within difference-blind institutions," which in fact may be "implicitly tilted towards the needs, interests, and identities of the majority group . . creat[ing] a range of burdens, barriers, stigmatizations, and exclusions for members of minority groups." Will Kymlicka, Comments on Shachar and Spinner-Halev: An Update from the Multiculturalism Wars, in MulTiCULTURAL QueSTIONS (Christian Joppke \& Steven Lukes eds., 1999).
} 
classes, such as women." ${ }^{25}$ Where group norms provide for discriminatory treatment of such classes, "the state's multicultural policies conflate the language of 'respect to groups' with a license to subordinate specific group members." ${ }^{26}$

Over the years, scholars and activists, particularly in the area of international development, have engaged the problem of women's rights and cultural tradition in the developing world in a number of ways. ${ }^{27}$ During the early 1970 s, the liberal feminist movement sought to end the invisibility of women in the economic life of impoverished nations by decrying "backward and oppressive traditions that constrain women's freedom. ${ }^{, 28}$ However, casually denouncing traditional practices as retrograde and incompatible with the modern concept of human rights glosses over the complex dynamics of the communities where those rules are applied. As Brenda Oppermann points out, "in many countries traditional law is often the only form of law known to many people, particularly those living in nonurban areas."29 Thus, customary or religious law may be the chief guarantor of order in communities where the state's reach is weak. ${ }^{30}$ In relation to the issue of sexual equality, the one-dimensional portrayal of women as

\footnotetext{
${ }^{25}$ Shachar, Group Identity and Women's Rights, supra note 7, at 289. Female members of minority groups may thus be subject to double-subordination as a "minority within a minority." See generally MINORITIES WITHIN MINORITIES: EQUALITY, RIGHTS, AND DIVERSITY (Avigail Eisenberg \& Jeff Spinner-Halev eds., 2005) (exploring conflicts between members within minority groups).

${ }^{26} I d$. at 291.

${ }^{27}$ See Celestine I. Nyamu, How Should Human Rights and Development Respond to Cultural Legitimization of Gender Hierarchy in Developing Countries?, 41 HARV. INT'L L.J. 381, 383 (2000).

${ }^{28}$ Id. at 384.

${ }^{29}$ Oppermann, supra note 7, at 66.

${ }^{30}$ Id. at 91; see also Leila Chirayath et al., Customary Law and Policy Reform: Engaging with the Plurality of Justice Systems 6 (2005) (background paper for the World Development Report 2006: Equality and Development, World Bank), available at http://siteresources.worldbank.org/INTWDR2006/Resources/477383-

1118673432908/Customary_Law_and_Policy_Reform.pdf(last visited May 13, 2006) ("Even if state systems do not lack legitimacy, they may be at odds with prevailing systems of conflict mediation within a particular community and/or be predominantly inaccessible due to geographical and socioeconomic barriers, or alternatively due to a luck of knowledge or awareness of the system on the part of political leaders .... In many cases state regimes do not have the capacity or legitimacy to fill in the gaps in social ordering and conflict resolution when local level systems are undermined ... when neither formal nor informal mechanisms are functioning, human rights abuses and serious conflict are more likely to occur.").
} 
long-suffering victims of pre-modern custom ignores the agency of individuals who live out each day ably negotiating their roles across the social landscape. ${ }^{31}$ This binary opposition between helpless Third World women and their liberated Western counterparts can thus reinforce colonialist stereotypes, ${ }^{32}$ with universalist notions of human rights ${ }^{33}$ masquerading as "the interrogation of one culture by another culture specifically, by the Western liberal culture ... that is a logical outgrowth of Christianity.,"34

The late 1970s ushered in a more class-conscious view of gender relations that relied heavily on Marxist ideals. ${ }^{35}$ This materialist view concerned itself with the broader

\footnotetext{
${ }^{31}$ See Leti Volpp, Feminism Versus Multiculturalism, 101 CoLUM. L. ReV. 1181, 1211 (2001); Hellum, supra note 4, at 644-46.

${ }^{32}$ Nyamu, supra note 27, at 386; see also Adrien Katherine Wing, Polygamy from Southern Africa to Black Britannia to Black America: Global Critical Race Feminism as Legal Reform for the Twenty-first Century, $11 \mathrm{~J}$. CONTEMP. LEGAL ISSUES 811, 814 ("Some westerners have been seen as trying to impose a western oriented value system that may reject polygamy and other cultural or religious practices as backward and sexist”); Cheryl B. Preston, Women in Traditional Religions: Refusing to Let Patriarchy (or Feminism) Separate Us from the Source of Our Liberation, 22 Miss. C.L. REV. 185, 194 (2003) (“. . . Western feminists may inadvertently reduce Third World Women to the category of victim."); Gila Stopler, Countenancing the Oppression of Women: How Liberals Tolerate Religious and Cultural Practices That Discriminate Against Women, 12 COLUM. J. GENDER \& L. 154, 209-10 (2003) (“ . . the way in which outsiders to the community assume and accept the existence of discriminatory practices against women in minority communities is in itself a form of racism since it is based on the feelings of superiority that the outsiders have toward the community ... [a] good example ... is the way in which the imperial powers in the nineteenth century justified colonization by pointing to women's inferior status in the subjugated cultures relative to their status in Europe ...").

${ }^{33}$ See Sundhya Pahuja, Comparative Visions of Global Public Order (Part I): The Postcoloniality of International Law, 46 HARV. INT'L L.J. 459, 466-469 (2005) (arguing the so-called "universal" human rights fail to include indigenous perspectives, thus reinforcing ideals of Western cultural superiority); Sally Engle Merry, From Law and Colonialism to Law and Globalization, 28 Law \& Soc. Inquiry 569, 582-83 (2003) (reviewing MARTIN CHANOCK, LAW, CUSTOM, AND SOCIAL ORDER: THE COLONIAL EXPERIENCE IN MALAWI AND ZAMBIA (1998)) (maintaining that the contemporary rhetoric of "traditional culture" "still impugns the rationality and inventiveness of traditional peoples, defined as those living in the developing countries of the global South.").

${ }^{34}$ Suzanne Last Stone, Cultural Pluralism, Nationalism, and Universal Rights, 21 CARDOZO L. REV. 1211, 1217 (2000); see also Pahuja, supra note 33, at 459. One concern among African human rights scholars has been the need for stronger protection of indigenous cultures on the international level. Because the right of religious freedom can include the right to proselytize, the spread of Christianity and Islam has been seen as an encroachment on traditional religious beliefs. See Makau wa Mutua, Limitations on Religious Rights: Problematizing Religious Freedom in the African Context, 5 BufF. Hum. RTS. L. REV. 75 (1999). ${ }^{35}$ Nyamu, supra note 27, at 383.
} 
socioeconomic inequalities that ultimately resulted in the exploitation of women. ${ }^{36}$

Accordingly, more basic concerns such as the right to food and shelter took precedence over "issues ... most easily identifiable as concerns to relatively privileged women in the West . . includ[ing] violations that threaten the freedom of movement, freedom of dress, freedom of bodily integrity, and freedom of control over one's sexuality."37 This stance contrasts with the classic feminist approach that focuses an allegedly disproportionate amount of attention on forms of "alien and bizarre oppression of women of color," such as "sati, dowry death, veiling, female genital surgeries, female infanticide, marriage by capture, purdah, polygamy, footbinding, and arranged marriages." ${ }^{38}$ Although the materialist view may draw attention to the larger structural conditions that result in female oppression, it has been criticized for being dismissive of the various cultural practices that have a specific and direct impact on women. ${ }^{39}$

A more recent, postmodern school of thought that developed in the 1980s focuses on the structure of gender relations and how the roles assigned to men and women perpetuates inequality. ${ }^{40}$ This view takes a "comprehensive approach to social relations [that] considers other forms of social differentiation (such as race, class, ethnicity, and age) to be as important as gender." ${ }^{41}$ Consequently, proposed remedial measures are designed to not just assist women, but also "change both gender roles and the system through which they are defined, demand[ing] far-reaching reform in gender relations,

\footnotetext{
${ }^{36}$ Id. at 386.

${ }^{37}$ Volpp, supra note 31, at 1210. Celestine Nyamu notes that "[w]ithin Western-based international women's rights scholarship and practice ... the issue of control of economic resources (including land) by women has not gained prominence. This omission stems from a bias in the human rights practice that emphasizes civil and political rights over economic, social, and cultural rights." Nyamu, supra note 27, at 399.

${ }^{38} I d$. at 1208.

${ }^{39}$ Nyamu, supra note 27, at 387.

${ }^{40}$ Id. at $383,387$.

${ }^{41} I d$. at 387 .
} 
especially at the family level."42 The radical reforms envisioned by the postmodern approach would be impracticable to achieve since they "require an overhaul of social, economic, and political institutions.

The majority of human rights groups pursue an "abolitionist approach" that echoes the feminist view's call to eliminate cultural practices that contradict the principles of international human rights law. ${ }^{44}$ The abolitionist approach thus seeks to achieve its goals by enacting legislation that would serve to substitute local custom. However, opponents of this brand of top-down reform have argued that the abolitionist approach frequently does not adequately consider the cultural context that surrounds controversial practices, thus failing to propose comprehensive solutions. Not surprisingly, local observers have bristled at the imperialist undertones of abolitionism, which advances proposals that are viewed as "decontextualized, hegemonic, and counterproductive for gender equality in practice." ${ }^{, 45}$

Indeed, the wholesale importation of Western political ideals and institutions can produce unintended consequences when applied across a vastly different cultural landscape. ${ }^{46}$ Furthermore, reforms that are aggressively imposed on a community from the outside may be interpreted as an assault on that community's identity, thus provoking more rigid interpretations of community tradition to the detriment of subordinated

\footnotetext{
${ }^{42} I d$.

${ }^{43} I d$. at 388 .

${ }^{44} I d$. at 392.

${ }^{45} \mathrm{Id}$. at 394.

${ }^{46}$ See Stone, supra note 34, at 1217 . For example, Woodman counsels that "it has been frequently observed an intervention by the state to change or suppress the oft-criticized practice of marriage payments ("bride-price", lobolo) may have far-reaching and unforeseen effects on the social structure of the people involved." Woodman, supra note 15, at 166.
} 
members. ${ }^{47}$ For example, the Indian Supreme Court's 1985 ruling in Mohammed Ahmed Khan v. Shah Bano Begum, ${ }^{48}$ which granted maintenance to a divorced woman beyond what was required by Islamic law, mobilized Muslim communities into mounting a successful campaign to have the legislature over the decision. ${ }^{49}$ India had already been experiencing intense sectarian strife at the time and thus many Muslims perceived Shah Bano as a "part of a pattern to assimilate [them] and others into the larger Hindu culture." ${ }^{, 50}$ Ironically, Muslim women living in multicultural India now have much more limited legal recourse in disputes over maintenance, unlike their counterparts in majority Muslim countries, such as Egypt. ${ }^{51}$

A preferable alternative to abolitionism incorporates both cross-cultural dialogue and internal discourse in arriving at solutions that protect the rights of women. ${ }^{52}$ This approach would recognize the value of international norms, but then tailor them to fit the circumstances on the ground. Thus, a deep understanding of the indigenous milieu, that is, "the meaning and dialing existential experience of culture," is essential. ${ }^{53}$ Indeed, lessons about the importance of the compatibility of foreign legal concepts to local circumstances are already being unearthed in the areas of corporate governance and

\footnotetext{
${ }^{47}$ See Jeff Spinner-Halev, Feminism, Multiculturalism, Oppression, and the State, 112 ETHICs 84, 96 (2001).

${ }^{48}$ (1985) 1 S.C.S. 96.

${ }^{49}$ Jain, supra note 5, at 215-17; Spinner-Halev, supra note 47, at 100.

${ }^{50}$ Spinner-Halev, supra note 47, at 100.

${ }^{51}$ Ayelet Shachar, Religion, State, and the Problem of Gender: New Modes of Citizenship and Governance in Diverse Societies, 50 McGILL L.J. 49, 68-69 (2005) [hereinafter Shachar, Religion, State, and the Problem of Gender].

${ }^{52}$ Nyamu, supra note 27, at 393-94.

${ }^{53}$ For outside observers, this can be achieved through the concept of "world traveling," a concept developed from Critical Race Feminism, wherein "we see ourselves in historical context, see ourselves as the 'other' might see us, and see the 'other' within her own complex cultural and legal context." Wing, supra note 32 , at 813 .
} 
antitrust law. ${ }^{54}$ Emerging literature on the so-called "transplant effect" illustrates how

legal systems that are transplanted from other countries, such as in the case of

colonialism, tend to be less effective as applied in receiving nations where there is a

"mismatch between preexisting conditions and transplanted law." 55 While similar

analyses have yet to be performed in other areas of law, it is reasonable to conclude that

any substantial program of legal reform should be carried out with the support of the

members of the community whose traditions will be affected. ${ }^{56}$

\section{A BRIEF POLITICAL HISTORY OF TANZANIA}

Missionary zeal in the nineteenth century first incited European interest in Tanganyika, ${ }^{57}$ with Germany occupying the region from the late 1800 s until the end of World War I. ${ }^{58}$ Following the war, Germany passed control of Tanganyika to Britain pursuant to a League of Nations mandate. ${ }^{59}$ During this time, the British chief representative had the power to make ordinances with respect to local customs and laws for the good government of the country. ${ }^{60}$ Britain then ruled Tanganyika as a United

\footnotetext{
${ }^{54}$ See generally Daniel Berkowitz, Katharina Pistor \& Jean-Francois Richard, The Transplant Effect, 51 AM. J. COMP. L. 163 (2003).

${ }_{56}^{55} \mathrm{Id}$. at 168.

${ }^{56}$ See Shachar, Religion, State, and the Problem of Gender, supra note 51, at 60; Spinner-Halev, supra note 47, at 107-08. For example, the campaign against female genital mutilation ("FGM") among the Sebei people of Uganda was initially met with resistance by community elders, who felt that the practice was an integral part of Sebei identity. Those leaders eventually became less defensive about such "outside interference" after women's groups began framing the issue of FGM in terms of health and safety, rather than human rights. Educational programs highlighting the dangers of FGM were ultimately successful, leading to a marked decline in the practice by the Sebei. See Tripp, supra note 4, at 427-32.

${ }_{57}$ History of Tanzania, http://www.tanzania.go.tz/historyf.html (last visited May 17, 2006)

${ }^{58}$ Background Note: Tanzania, U.S. Dep't of State, Mar. 2006, http://www.state.gov/r/pa/ei/bgn/2843.htm [hereinafter History].

${ }^{59}$ Id. The German Empire ceded its colonies to Allied powers by virtue of Article 119 of the Versailles Peace Treaty. Norrie, supra note 2, at 397. In 1918, the U.S. President Woodrow Wilson announced that the German colonies "should be declared the property of the League of Nations." Kenneth Ingham, Tanganyika: The Mandate and Cameron 1919-1931, in HISTORY OF EAST AFRICA 544 (Vincent Harlow ed., 1965).

${ }^{60}$ Ingham, supra note 59.
} 
Nations trust territory after World War II. ${ }^{61}$ The mid-twentieth century saw the first organized local elections and in December 1959, Britain granted self-government to Tanganyika following general elections that were held in August $1960 .^{62}$ In May 1961, Tanganyika achieved autonomy and wrote a new constitution. ${ }^{63}$ Full independence was secured on December 9, $1961 .^{64}$

Zanzibar began as an early Arab/Persian commercial center. ${ }^{65}$ The Portuguese established a trading post in Zanzibar in the latter part of the sixteenth century ${ }^{66}$ and dominated it throughout the seventeenth century. ${ }^{67}$ Omani Arabs retook Zanzibar in the early eighteenth century and by 1840 Sultan Seyyid Said transferred his capital from Muscat to Zanzibar. ${ }^{68}$ Zanzibar functioned as an independent Arab state until it became a British protectorate in the late nineteenth century. ${ }^{69}$ In exchange for the right to maintain the throne of Zanzibar, the sultan transferred all foreign relations matters to the British officials. $^{70}$ Britain continued to rule Zanzibar through the sultanate until after World War II. $^{71}$ During the mid-1940s, Britain began establishing local village and government councils. $^{72}$ Six years after the first local elections took place in 1957, Zanzibar received

\footnotetext{
${ }^{61}$ History, supra note 58.

${ }^{62} I d$.

${ }^{63} I d$.

${ }^{64} I d$.

${ }^{65}$ Id.

${ }^{66}$ Barbara Lee Diamonstein, Zanzibar's Exotic Medley, N.Y. TIMES, Apr. 30, 1989, at 8.

${ }^{67}$ History, supra note 58.

${ }^{68} \mathrm{Id}$.

${ }^{69}$ Stiles, A Kadhi and His Court, supra note 1.

${ }^{70}$ J.E. Flint, Zanzibar 1890-1950, in HISTORY OF EAST AFRICA, supra note 4, at 641. Following the creation of the protectorate, the sultan gradually lost all political and financial control over Zanzibar. Despite the sultan's power to choose his own successor, as early as 1892, the British chose and installed the succeeding Zanzibari sultans. Id. at 641-46. Subsequent attempts to recover power by the Arab princes were met with military action by the British. Id.

${ }^{71}$ History, supra note 58.

${ }^{72}$ Flint, supra note 70, at 669.
} 
its independence from the United Kingdom, thus becoming a constitutional monarchy under the sultan. ${ }^{73}$

In 1964, Zanzibar joined with Tanganyika three months after Zanzibari nationalists overthrew the archipelago's Arab sultan in a bloody revolution. ${ }^{74}$ The United Republic of Tanzania was born on October $29,{ }^{75}$ with Zanzibar maintaining significant political autonomy. ${ }^{76}$ In the late 1970 s, the Tanganyika African National Union (TANU), which was the chief political party in the mainland, merged with the Afro-Shirazi Party (ASP) of Zanzibar to form the CCM (Chama cha Mapinduzi-CCM Revolutionary Party). ${ }^{77}$ This union was ratified pursuant to the Tanzanian constitution of 1977 and reinforced under later versions of the charter in 1982 and $1984 .^{78}$

\section{DEVELOPMENT OF TANZANIA'S LEGAL SYSTEMS}

\section{A. Tanganyika}

The legal system in colonial East Africa created different systems of justice for Europeans and indigenous persons. ${ }^{79}$ For natives of Tanganyika, Germany created a judicial system that was closely tied to executive authority. ${ }^{80}$ Colonial district officers in charge of military stations could delegate adjudication of disputes to local leaders who also exercised executive functions. ${ }^{81}$ They were instructed to decide cases using local law because the German administration considered the Africans "insufficiently advanced

\footnotetext{
${ }^{73} I d$.

${ }^{74}$ Simon Robinson, A Whiff of Revolt On Spice Islands; Thirty-six years after its union with Tanzania, Zanzibar considers divorce, TIME, Oct. 30, 2000.

${ }^{75}$ History, supra note 58.

${ }^{76} \mathrm{Id}$.

${ }^{77}$ Id.

${ }^{78} I d$.

${ }^{79}$ Norrie, supra note 2, at 396.

${ }^{80}$ Anthony Allott, Development of the East African Legal System During the Colonial Period, in HISTORY OF EAST AFRICA 348 (D.A. Low ed., 1976).

${ }^{81} I d$. at $396-97$.
} 
to come under German law." ${ }^{, 82}$ Although the native law courts were not subject to any strict rule of law, they were to abide by general legal considerations and common sense. ${ }^{83}$ Following the German handover of its colonies to the Allied Parties, Britain established the Tanganyika Order in Council as the basic law for the territory encompassing Tanganyika. ${ }^{84}$ Britain further enacted the Courts Ordinance to "regulate the administration of justice in the territory." 85 The Courts Ordinance maintained the previous system of separate adjudication for foreigners and the indigenous population ${ }^{86}$ although appeals from the native courts could be sent to the colonial High Court. ${ }^{87}$ Similar to the German design, the local tribunals were to be governed by the laws of the indigenous population as long as the laws were not "repugnant to justice and morality.",88 For the white population of Tanganyika, Britain established courts of common law, including a district magistrate court, a resident magistrate court, and the High Court. ${ }^{89}$

\footnotetext{
${ }^{82}$ Id. at 397.

${ }^{83} \mathrm{Id}$. "The indigenous systems ranged in sophistication all the way from a centralized, highly developed, judicial structure and precisely formulated law ... to the decentralized, mainly arbitral, adjudicatory institutions and more elastic legal systems. Allott, supra note 80, at 365-66. Europeans in British East Africa mainly viewed local indigenous systems as barbaric in their punishments and arbitrary in their modes of conviction and accusation. $I d$. at 366. Traditional courts were allowed to continue due to a want of "necessary power" and "administrative machinery." Id.

${ }^{84}$ Norrie, supra note 2, at 397.

${ }^{85} \mathrm{Id}$.

${ }^{86} I d$. Unlike the Germans, however, responsibility for native courts was placed "fully and solely" in the hands of the British administration. Allott, supra note 80, at 372. However, the British administration tried to preserve the previous nature of these courts. Eugene Cotran, Tribal Factors in the Establishment of the East African Legal Systems, in TRADITION AND TRANSITION IN EAST AFRICA 130 (P.H. Gulliver ed., 1969). The courts were made up of traditional local chiefs who also exercised executive power in the community, only had jurisdiction over the African population, and applied the customary law of the area. $I d$.

${ }^{87}$ Norrie, supra note 2, at 398.

${ }^{88} \mathrm{Id}$. Such repugnancy clauses were also used in other British colonial jurisdictions, such as West Africa, India, and New Zealand. See Modibo Ocran, The Clash of Legal Cultures: The Treatment of Indigenous Law in Colonial and Post-Colonial Africa, 39 AKron L. REV. 465, 470, 475 (2006); Nan Seuffert, Shaping the Modern Nation: Colonial Marriage Law, Polygamy and Concubinage in Aotearoa New Zealand, 7 LTC 186 (2003), J.N. Matson, The Common Law Abroad: English and Indigenous Laws in the British Commonwealth, 42 INT'L \& COMP. L.Q. 753, 760-61 (1993).

${ }^{89}$ Norrie, supra note 2, at 398-90. "The High Court had an exclusive and a concurrent original jurisdiction as well as one as a court of appeal. A further appeal lay to the Court of Appeal for Eastern Africa (in Kenya)." Id. At this time, under the British administration, most of East Africa had become a "largely integrated law area", despite the region's divergent histories. Allott, supra note 80, at 350 . In the early
} 
As with its other East African territories, Britain enacted a legal code based on the statutes it enforced in India. ${ }^{90}$

According to Eugene Cotran, this dual system resulted in "an almost complete isolation of the African courts and customary law in the colonial era ... Furthermore, there appears to have been a general lack of interest by the colonial governments in the problems arising from the content and application of the customary law."91 This apathy meant that the British made no effort to study or record customary law, ${ }^{92}$ the principles of which were treated as a matter of fact and not law. ${ }^{93}$ As a result, conflicts between customary and statutory law remained unresolved. ${ }^{94}$ Furthermore, customary law was not the province of the professional lawyer because advocates could not appear before the African courts. ${ }^{95}$

Following independence in 1961, Tanganyika became a member of the British Commonwealth and terminated the system of appeals to the Crown. ${ }^{96}$ Most notably, Tanganyika instituted a complete separation between the executive and the judiciary and eliminated the parallel, raced-based court system. ${ }^{97}$ During this time, the challenge for Tanganyika and its East African neighbors was to unify their legal systems so that "no one should find himself living at one and the same time under two kinds of law, English

1950s, the British system was reviewed and reforms were introduced in Tanganyika. Id. at 375 . Native courts became "local courts: and although still customary in origin and jurisdiction, had specialized benches with more sophisticated backgrounds. Id. This development was to foreshadow the evolution of local court systems in Tanzania. Id.

${ }^{90}$ See generally Allott, supra note 80.

${ }^{91}$ Cotran, supra note 86, at 131-132.

${ }^{92} \mathrm{Id}$. at 132.

${ }^{93} \mathrm{Id}$.

${ }^{94} I d$. at $132-33$.

${ }^{95} \mathrm{Id}$. at 133.

${ }^{96}$ Norrie, supra note 2, at 400.

${ }^{97}$ Id. 
and African, and in the sense that persons of different communities or races should not find themselves, by reason only of their origin, placed under different legal systems." 98 The Magistrates' Courts Acts of 1963 and 1984 established a unitary three-tier court system in Tanganyika. ${ }^{99}$ The first tier consists of subordinate courts, including primary courts, district courts, and resident magistrates' courts. ${ }^{100}$ The primary court is the lowest court in the country, with jurisdiction extending to civil cases where the applicable law is customary or Islamic law, as well as disputes involving minor civil debts and matrimonial proceedings. ${ }^{101}$ The High Court ${ }^{102}$ follows in the hierarchy and exercises jurisdiction over Tanganyika only. ${ }^{103}$ The Court of Appeal is the highest court and is competent to hear appeals from both Tanganyikan and Zanzibari court decisions. $^{104}$

\section{B. Zanzibar}

The development of the Zanzibari legal system differed from that of Tanganyika. Although a minority, Arabs created a strong Arab-Muslim influence on Zanzibar by virtue of their economic dominance. ${ }^{105}$ During the British protectorate era, the courts

\footnotetext{
98 Allott, supra note 80 , at 382.

${ }^{99}$ Norrie, supra note 2 , at 400 . At this time, Tanganyika chose to have one written criminal code applicable to all its residents. Cotran, supra note 86, at 143. In terms of civil law, Tanganyika chose a fullscale unification of all customary laws. $I d$. This approach was criticized because 1) the unified laws do not represent the law of any one tribe; 2) the unified law would not satisfy any of the communities; 3 ) the reforms were half-hearted; 4) people would avoid the courts; and 5) codification hinders development of new legislation. Id. at 143-144. For more on community responses to this campaign of legal unification, see M.E.R. Nicholson, Change without Conflict: A Case Study of Legal Change in Tanzania, 7 LAW \& SOC'Y REV. 747 (1973).

${ }^{100}$ Norrie, supra note 2 , at 400.

${ }^{101} \mathrm{Id}$.

${ }^{102}$ See TANZ. CONST. (1997) art. 108(1)

103 "Except where the law confers jurisdiction specifically on the 'High Court of Tanzania."” Norrie, supra note 2 , at 402 .

${ }^{104}$ Id. at 403 .

${ }^{105}$ Id. at 399 .
} 
were comprised of a British jurisdiction and a Zanzibari one. ${ }^{106}$ The former consisted of a High Court and lower courts called British subordinate courts. ${ }^{107}$ As in other East African territories, the civil and criminal codes of British India applied. ${ }^{108}$ A parallel system existed for Zanzibar, consisting of the Sultan's Court and the subordinate courts. ${ }^{109}$ The subordinate courts consisted of first-, second-, and third-class subordinate courts, kadhis' courts, and juvenile courts. ${ }^{110}$ The kadhis' courts 'administered a limited range of civil litigation in which the parties were Muslims."111

Following Britain's grant of self-government in 1963, Zanzibar drafted the Constitution of the State of Zanzibar. ${ }^{112}$ The Courts Decree, which was enacted after the fall of the sultan's government in 1964, created the High Court ${ }^{113}$, district courts, kadhis' courts, primary courts, and juvenile courts. ${ }^{114}$ The British courts were abolished after independence.

The People's Court Decree 1969 introduced a separate court structure for Zanzibar, comprised of the people's area courts, the people's district courts, the kadhis' courts, the High Court, and the Supreme Council. ${ }^{115}$ Legislation in 1984 and $1985^{116}$

\footnotetext{
${ }^{106} I d$. Indeed, the first British jurisdiction established in East Africa was in the Sultanate of Zanzibar. Allott, supra note 80, at 350. "The most important legal fact about the East African territories was that they abutted on the Indian Ocean. The system of codified law introduced into British India, the criminal and civil courts and the procedure that they followed, were copied or applied in the British East African possessions; and it was through Zanzibar that this Indian influence came to the mainland territories." Id. The 1884 Order in Council (Art. 8(a)) even directed British courts in Zanzibar to apply the Statute law as applied by courts in Bombay. Id. at 351. Appeals from the British sphere on the East Coast of Africa (except for Zanzibar) were to be sent to the Supreme Court at Bombay. Id. at 354 .

${ }^{107}$ Norrie, supra note 2, at 399.

${ }^{108}$ See generally Allott, supra note 80, at 348-368.

${ }^{109}$ Norrie, supra note 2, at 399.

${ }^{110} \mathrm{Id}$.

${ }^{111} I d$.

${ }^{112} I d$. at 403 .

${ }^{113}$ Article 92 of the Constitution also established the High Court. Id. at 403 n.50.

${ }^{114}$ Courts Decree, No. 22 of 1963; see also id. at 403.

${ }^{115} I d$. In the late 1970 s, Zanzibar also drafted the Constitution of the Revolutionary Government of Zanzibar 1979. Id.

${ }^{116}$ See High Court Act 1985; Kadhis’ Court Act 1985; Magistrates' Courts Act 1985.
} 
ended the system of people's courts and replaced it with common law-style adjudication. ${ }^{117}$ This legislation ushered in three types of courts in Zanzibar: the High Court of Zanzibar, the kadhis ' court, and the magistrates' court. ${ }^{118}$

The High Court is the chief court in Zanzibar and enjoys unlimited jurisdiction over both civil and criminal cases. ${ }^{119}$ Appeals from the High Court lie with the Court of Appeal of Tanzania. ${ }^{120}$ Below the High Court are three types of magistrates' courts. ${ }^{121}$ The primary magistrate court has limited civil and criminal powers, ${ }^{122}$ while the district court has both original and appellate jurisdiction along with greater civil and criminal powers. ${ }^{123}$ The resident magistrates exercises original and appellate jurisdiction and hears all cases from the district magistrates' courts. ${ }^{124}$

The Kadhis' Courts Act of 1985 established kadhis' courts for every district and a Chief Kadhi's Court for Zanzibar. ${ }^{125}$ The jurisdiction of the kadhis' courts is restricted to questions of Muslim law in regards to personal status, marriage, divorce, and inheritance, as well as cases where all parties profess the Islamic faith. ${ }^{126}$ The rules of evidence applicable in a kadhi court depart from the rules normally prescribed by Islamic law:

This departure is noticeable in two areas: in hearing evidence all witnesses called shall be heard without discrimination on grounds of religion, sex or otherwise; and each issue of fact shall be decided upon the assessment of

\footnotetext{
${ }^{117}$ Norrie, supra note 2, at 404.

${ }^{118}$ Id.

${ }^{119} \mathrm{Id}$.

${ }^{120} I d$. The Court of Appeal of Tanzania has no jurisdiction in respect to interpreting the Constitution of Zanzibar, Islamic matters originating in the kadnis' courts, and any other matter approved under the Constitution of Zanzibar or any other law enacted by the Zanzibar House of Representatives. Id.

${ }^{121} I d$. at 405 . The three types of magistrates' courts are resident magistrates' courts, district courts, and primary courts; all established by the Magistrates' Court Act 1985. Id.

${ }^{122} I d$. at 406.

${ }^{123} \mathrm{Id}$.

${ }^{124}$ Id.

${ }^{125}$ Kadhis' Courts Act 1985, Act No. 3.

${ }^{126}$ Norrie, supra note 2, at 407.
} 
credibility of all evidence before the court and not upon the number of witnesses who have given evidence. ${ }^{127}$

The Chief Kadhi's Court acts as an appellate court for all kadhis' courts and has no original jurisdiction. ${ }^{128}$ Appeals from the Chief Kadhi's Court lie with the High Court, wherein the judges, along with four sheikhs, decide cases according to a majority vote, ${ }^{129}$ which is final. ${ }^{130}$

\section{United Republic of Tanzania}

Although Tanzania is a nation with two distinct court systems, the Court of Appeal and the Constitutional Court are two venues for judicial cooperation. The Court of Appeal of Tanzania is the highest court in the Republic ${ }^{131}$ and can only hear appeals from the High Court and subordinate courts with special jurisdiction. ${ }^{132}$ The special Constitutional Court, which is provided for in both the Constitution of Zanzibar ${ }^{133}$ and the Constitution of the Republic of Tanzania, ${ }^{134}$ is charged with hearing disputes arising from interpretation of the Union Constitution "where such interpretation or its application is in dispute between the Government of the United Republic and the Revolutionary

\footnotetext{
${ }^{127}$ Id. at 407. In 1998, lawmakers in Tanganyika drafted a bill that would reestablish the kadhis' courts on the mainland, though ultimately no legislation was ever enacted. Interestingly, these tribunals would retain the traditional Islamic laws of evidence, unlike the courts that were already operating in Zanzibar. Robert Makaramba, The Secular State and the State of Islamic Law in Tanzania: With Particular Reference to Kadhi's Courts Establishment Proposal 9 (July 2000) (paper presented at the Islamic Law in Africa Project Symposium, Dar es Salaam, Tanzania, July 21-23, 2000) (on file with author).

${ }^{128}$ Kadhis' Court Act.

${ }^{129} \S 10(2)$; see also Norrie, supra note 2, at 407.

$130 \S 10(3)$.

131 TANZ. CONST (1997) part IV.

${ }^{132}$ Appellate Jurisdiction Act, No. 15 of $1979 \S 3$.

${ }^{133}$ ZANZIBAR CONST. art. 123(2)(a).

${ }^{134}$ TANZ. CONST. arts. 125-128.
} 
Government of Zanzibar."135 The Constitutional Court reportedly has never met, as "any attempt to convene could be easily interpreted as an attempt to undermine the Union.",136

\section{THE LAW OF MARRIAGE AND DIVORCE IN TANZANIA}

\section{A. Unification of Marriage Law in Tanganyika: The Law of Marriage Act}

The movement for the unification of laws during the early postcolonial period in East Africa was most pronounced in the area of family law, which had been particularly beleaguered by the choice of law problems created by the plural legal system inherited from the British. ${ }^{137}$ The fact that individuals "rarely confined their actions within one system of law" encouraged much confusion and mischief. ${ }^{138}$ For example, Bart Rwezaura has noted the phenomenon of Christian men who enter into monogamous marriages and then use customary law to acquire additional wives, only to disavow obligations towards a subsequent spouse by disputing the legal effect of the later relationships. ${ }^{139}$ Additionally, courts dividing the property of persons who died intestate

${ }^{135}$ Id. at art. $126(1)$.

${ }^{136}$ Norrie, supra note 2, at 409. In discussing the ineffectiveness of the Constitutional Court, Norrie states: "First, it must be noted that this Court has no basis in the Constitution. To hear and settle disputes between the United Republic and Zanzibar is essentially a Union matter neither a constituent assembly ... nor the Fifth Amendment made it a Union matter . . . Second, as the Constitution of the United Republic stipulates that Tanzania Mainland has no separate executive and legislature but is governed by the Union executive and legislature, and as the Zanzibaris are constitutionally represented in the government and legislature, it is impossible to settle disputes between Tanzania Mainland and Zanzibar." Id.

${ }^{137}$ Bart Rwezaura, Tanzania: Building a New Family Law Out of a Plural Legal System, 33 U. LOUISVILLE J. FAM. L. 523, 523-524 (1995) [hereinafter Rwezaura, Building a New Family Law].

${ }^{138} I d$. at 524. For issues that are to be decided according to customary or religious law, courts apply the "mode of life test" and examine whether an individual has lived his life in concert with a particular tradition or faith. This test thus determines which of the three main bodies of law shall resolve the controversy. Rakstad et al., supra note 14, at 93.

${ }^{139}$ Rwezaura, Building a New Family Law, supra note 137, at 524-25 (“. . . because of social and economic transformation, including the influence of Christianity, as well as the growth of urban centers, a number of Africans became partially incorporated into the Western system."). 
were often left with the unenviable task of deciding which rules to apply based on the community to which that individual purportedly belonged. ${ }^{140}$

In order to untangle the competing bodies of family law, the African Conference on Local Courts and Customary Law was held in Dar es Salaam in $1963 .^{141}$ This conference inspired the government of Kenya to create the Commission on the Law of Marriage and Divorce in 1967, which issued a report the following year and urged reform and integration of the disparate systems of religious, customary, and law via a proposed Law of Matrimony Act. ${ }^{142}$ Ultimately, the Commission's efforts stalled in Kenya, where the draft bill was rejected by the legislature multiple times on the grounds that it was "unAfrican, a model of English law that took insufficient account of African customs and traditions and gave too many rights to women."143

Tanzania, however, adopted the Kenyan model in overhauling its own family law system. ${ }^{144}$ Mapendekazo ya Serikali juu ya Sheria ya Ndoa (Government's Proposals on Uniform Law of Marriage), Government Paper No. 1 of 1969, incorporated most of the reforms advanced by the Kenyan draft bill and provided the groundwork for Tanzania's

\footnotetext{
${ }^{140} \mathrm{Id}$. at 525 .

${ }^{141}$ Andreas Rahmatian, Termination of Marriage in Nigerian Family Laws: The Need for Reform and the Relevance of the Tanzanian Experience, 10 INT'L J.L. POL. \& FAM. 281, 297 (1996).

${ }^{142} \mathrm{Id}$.

${ }^{143} \mathrm{Id}$. For accounts of how the state of family law in Kenya has fared over the years, see Abdulkadir Hashim, Muslim Personal Law in Kenya and Tanzania: Tradition and Innovation, 25 J. MUSLIM MINORITY AfF. 449 (2005), Catherine A. Hardee, Note, Balancing Acts: The Rights of Women and Cultural Minorities in Kenyan Marital Law, 79 N.Y.U. L. REV. 712 (2004), and Eugene Cotran, Marriage, Divorce and Succession Laws in Kenya: Is Integration or Unification Possible?, 40 J. AFR. L. 194 (1996).

Similarly, Tanzania took another cue from its neighbors when it passed the 1999 Land Act, which included a clause guaranteeing spousal co-ownership of land. The issue was already being debated in Uganda, where efforts to adopt co-ownership legislation inspired activists in Tanzania to have similar measures enacted in their country. While the Tanzanian campaign resulted in success, the opposite was true for Uganda, where even attempts to reform family law dating back to 1904 had already been stymied for decades. Tripp, supra note 4, at 426.

${ }^{144}$ James S. Read, A Milestone in the Integration of Personal Laws: The New Law of Marriage and Divorce in Tanzania, 16 J. AFR. L. 19, 19 (1972).
} 
groundbreaking Law of Marriage Act, 1971 ("LMA" or "the Act"). ${ }^{145}$ Those reforms included the recognition of religious and customary marriages, registration requirements, the establishment of marriage conciliation boards, the requirement of a judicial decree as a prerequisite to a valid divorce, and the presumption of marriage based on a two-year period of cohabitation. ${ }^{146}$ Although these changes appeared to enjoy widespread support among certain sectors of the political class, ${ }^{147}$ some have questioned whether the general public had an adequate opportunity to debate the merits of the proposed LMA before it came into effect. ${ }^{148}$ Nevertheless, the Tanzanian parliament's proactive stance garnered it credit for "tak[ing] the pioneering step of enacting the first measure in Commonwealth Africa (or indeed in any of the Commonwealth states with comparable problems of plural legal systems) to integrate the diverse personal laws of marriage and divorce which were formerly applicable."149

\section{Key Statutory Provisions}

\section{a. General Scope and Definition of Marriage}

Although the LMA represents a significant step in the integration of family law, the unification of marriage and divorce laws under the LMA is far from absolute. Spanning 167 sections, the statute supplanted the much-weaker Declaration of Customary Law and covers a broad range of issues previously governed by the various legal regimes

\footnotetext{
${ }^{145} \mathrm{Id}$.

${ }^{146} I d$. at 21.

${ }^{147}$ See Rakstad et al., supra note 14, at 96-97 (noting that the passage of the LMA "was influenced by the UWT [Umoja wa Wanawake Tanzania], the women's wing of the ruling party").

${ }^{148}$ Although the government was required to publish a translation of the original English language bill into Kiswahili, the translation was only available to the public three weeks before the president approved the bill. Read, supra note 144, at 22.

${ }^{149}$ Id. at 19 .
} 
operating among Tanzania's disparate communities. ${ }^{150}$ While the Judicature and Application of Laws Ordinance and the Magistrates' Courts Act provide for the application of religious and customary law in certain civil matters, the LMA supercedes the patchwork of marriage and divorce laws, ${ }^{151}$ "the precise inter-relationship between which was ill-defined and gave rise to some difficult questions of conflict of laws.",152 Because family law is not considered a Union matter, however, the LMA applies only in mainland Tanganyika and not in Zanzibar. ${ }^{153}$ Thus, only individuals in Tanganyika may rely on reforms promulgated by the LMA.

The LMA also provides for only a partial integration of family law by applying special accommodations for certain religious marriages. ${ }^{154}$ Under the statute, a marriage is defined as "the voluntary union of a man and a woman, intended to last for their joint lives" $" 155$ and may either be monogamous (or intended to be monogamous) or polygamous (or potentially polygamous). ${ }^{156}$ On one hand, the LMA exhibits great regard for

\footnotetext{
${ }^{150}$ See generally Law of Marriage Act, 1971 [hereinafter LMA]; see also Barthazar A. Rwezaura \& Ulrike Wanitzek, Family Law Reform in Tanzania: A Socio-Legal Report, 2 INT'L J.L. \& FAM. 1, 7 (1988). For an introduction into the legal systems of Tanzania's most prominent religious and customary communities, see Adam Haji Bakari, The Sharia Marriage Practices Amongst the Islamic Communities in Tanzania, 52 PUNJAB U. L.J. 55 (1994) (describing the application of Islamic family law in Tangyanika) and G. Nasieku Tarayia, The Legal Perspectives of the Maasai Culture, Customs, and Traditions, 21 ARIZ. J. INT'L \& COMP. LAW 183, 201-204 (2004) (surveying the customary marriage laws of the Maasai people).

${ }^{151}$ Bakari, supra note 150, at 62 (1994) (citing JALO § 9(5)) ("Notwithstanding the provision of this Ordinance, the rules of customary law and the rules of Islamic law shall not apply in regard to any matter provided for in the Law of Marriage Act 1971.").

${ }^{152}$ Read, supra note 144, at 20.

${ }^{153} I d$. at 21 .

${ }^{154}$ Rahmatian, supra note 141, at 298 (observing that the idea that "[t] he law should interfere with religious and customary practice as little as possible ... prevented an entire unification of marriage laws").

${ }^{155}$ LMA $\S 9(1)$. While the issue of same-sex marriage falls outside the scope of this paper, the restrictive definition of marriage as found in the LMA will certainly become increasingly problematic as same-sex relationships receive greater recognition within the international community. Indeed, South Africa already has the distinction of being the first country on the continent to permit persons of the same gender to marry. Craig Timberg, S. Africa's Top Court Blesses Gay Marriage, WASH. POST, Dec. 2, 2005, at A16.

${ }^{156}$ LMA $\S 10(1)$. James S. Read criticizes the surplassage of the language relating to "potentially polygamous" marriages by observing that the definition of "polygamous marriage" "has already been defined to embrace potentiality, as well as the actuality." Read, supra note 144, at 24 . The final LMA differs from the Kenyan draft bill in that it has done away with the offence of bigamy in situations where an
} 
marriages performed under Islamic and customary law by allowing for polygamous unions and even presuming that those relationships are potentially polygamous by allowing a husband and wife to convert their monogamous marriage into a polygamous one (and vice versa) by joint declaration. ${ }^{157}$ On the other hand, the statute also defers to Christian sensibilities by declining to extend this privilege of convertibility to marriages "celebrated in a church in Christian form ... for so long as the parties continue to profess the Christian faith." ${ }^{158}$ While the LMA thus sanctions polygamy in many cases, polyandry is strictly prohibited. ${ }^{159}$

One of the more controversial portions of the LMA is the provision establishing common law marriage. ${ }^{160}$ If a couple has cohabited for a period of at least two years "in such circumstances as to have acquired the reputation of being husband and wife," a rebuttable presumption of marriage arises. ${ }^{161}$ Where that presumption has been rebutted, the woman may still apply for maintenance for both herself and her children if she can show that the couple "did in fact live together as husband and wife for two years or more." 162 In such scenarios, the court also has the power to award custody of the

officially monogamous husband enters into a second marriage. Id. at 26. However, the second marriage will still be considered void and the man may be liable for falsely stating his true marital status if he gives public notice of that later union. Id.

${ }_{158}^{157}$ LMA $\S 11(1)$.

158 § 11(5). See also Rahmatian, supra note 141, at 298 ("[Section 11(5)] confers a special status on the Christian monogamous marriage within the otherwise unified secular law"); Read, supra note 144, at 23 ("the Act ... makes conversion of a Christian marriage conditional upon apostasy").

${ }^{159} \S \S 152(1),(2)$. Contracting a polyandrous marriage will subject parties to imprisonment for a maximum of three years. $\S 152(3)$.

${ }^{160} \S 160$; see also Bart Rwezaura, Proposed The Abolition of De Facto Unions in Tanzania: A Case of Sailing against the Social Current, 42 J. AFRICAN L. 187, 187-88 (1998) [hereinafter Rwezaura, Proposed Abolition].

${ }^{161} \S 160(1)$

$162 \S 160(2)$. 
children, order maintenance payments or "grant such other reliefs . . . as it has

jurisdiction under [the] Act." 163

\section{b. Prerequisites to Marriage}

Despite the LMA's deference to religious and customary tenets in establishing the marriage relationship, the Act contains numerous provisions that are generally applicable to all communities. The minimum age for marriage is eighteen years old for males and fifteen for females. ${ }^{164}$ However, courts may in their discretion waive this requirement to allow marriage between minors where either party has obtained the age of fourteen and there exist "special circumstances which make the proposed marriage desirable.",165 Persons must enter into the union with freely given consent, ${ }^{166}$ or in the case of girls below the age of eighteen, obtain consent from the bride's father. ${ }^{167}$ Furthermore, marriages with certain close relatives are strictly prohibited. ${ }^{168}$ However, the Act also makes marriage more accessible by eliminating the payment of bride price as a prerequisite, ${ }^{169}$ which is a common practice among many customary and religious communities. $^{170}$

\footnotetext{
${ }^{163} \mathrm{Id}$.

${ }^{164}$ LMA $\S 13(1)$. Knowingly entering into a marriage with a person below the minimum age carries a punishment of three years imprisonment. $\S 148(1)$. Furthermore, a maximum prison sentence of two years is reserved for those who participate in a ceremony solemnizing such a union knowing that either party is underage. $\S 148(2)$.

$165 \S \S 13(2)(\mathrm{a})-(\mathrm{b})$.

$166 \S 16(1)$.

$167 \S 17(1)$ (a). Consent will be unnecessary if the both bride's mother and legal guardian also happen to be dead. $\S \S 17(b),(c)$. Although forced marriages actually do not have a concrete basis in either the Qur'an or under Islamic tradition, the majority of religious scholars in Tanzania and neighboring countries believe that such marriages are not invalid, despite the bride's lack of consent. Bakari, supra note 150, 76-77.

${ }^{168}$ See generally LMA $\S 14$.

$169 \S 41(a)$.

${ }^{170}$ Under Islamic law, the dowry is a part of the marriage contract and upon payment becomes the property of the bride. However, largely due to socioeconomic reasons, Muslim families have been known to do
} 
The LMA imposes a notice requirement, wherein parties to a marriage must inform a registrar or registration officer of their intent to marry at least three weeks before the proposed date of the ceremony. ${ }^{171}$ The official must then publicize news of the impending nuptials, thus providing individuals an opportunity to come forward with any objections to the relationship. ${ }^{172}$ With regard to polygamous unions, the LMA gives the current wife (or wives) the right to object to additional spouses if the husband is of limited means and the marriage would likely cause hardship to the family, or if the would-be wife is "of notoriously bad character," inflicted with a communicable disease or is "likely to introduce grave discord into the household."173 A court or marriage conciliation board may hear an objection and in the presence of the parties involved, make a fact-based determination as to whether the marriage should be allowed to proceed. ${ }^{174}$

\section{c. The Marriage Contract}

away with the dowry requirement or divert payment to the bride's parents. Such practices contradict Islamic law. Bakari, supra note 150, at 73.

${ }^{171} \S 18(1)$. This public notice must include basic information regarding the couple, such as the names, ages, and residences of the parties and their parents; the proposed date and location of the ceremony; a statement that the impending marriage is not prohibited by law; and a classification of the marriage as either monogamous or polygamous (or potentially polygamous). $\S \S 18(2)(\mathrm{a})-(\mathrm{c}),(\mathrm{f}),(\mathrm{g})$. Another provision that enshrines Christian mores into law is the requirement that a man who intends to enter into a marriage celebrated according to Christian tradition prepare a declaration that he is not already married to another woman. $\S 18(i)$. Nevertheless, a couple's failure to provide proper notice will not invalidate a marriage. $\S 41(b)$.

$172 \S 19$.

$173 \S 20(2)$. While the recognition of polygamy under secular law was intended to placate the concerns of traditional Muslims and members of customary communities, the right of objection arguably represents a compromise that simultaneously attempts to protect the interests of women. Rwezaura, Proposed Abolition, supra note 160, at 190.

${ }^{174} \S 22(1)$. 
A marriage may be contracted either civilly or according to the rites of a particular religion or customary community. ${ }^{175}$ The Act provides a definition of Muslim marriage and Christian marriage. The former is "contracted in the manner recognized by Islam or by any school or sect of that faith," 176 while the latter is "celebrated in a church in the manner recognized by Christian faith or by any denomination or sect of that faith."177 An Islamic marriage may be celebrated according to Islamic rites by a kadhi or a registration officer who is a Muslim. ${ }^{178}$ Either an Islamic cleric or a registration officer who is a Muslim may apply to become a licensed kadhi. ${ }^{179}$ Two witnesses must be present at the time of contracting, ${ }^{180}$ the celebration of which is open to public in cases of civil marriage. ${ }^{181}$ For religious and customary marriages, members of that faith or community are allowed to attend. ${ }^{182}$

\section{d. Marriage Registry}

One significant step towards the efficient administration of marriage laws in Tanganyika is the establishment under Part III of the LMA of registries tracking marriages, annulments, and divorces. ${ }^{183}$ The mainland is divided into registration districts, with a registrar assigned to each district. ${ }^{184}$ The registrar is obligated to record civil marriages, while religious officials have a duty to register the nuptials over which

\footnotetext{
${ }^{175}$ LMA § 25(1).

${ }^{176} \S 25(3)(a)$.

$177 \S 25(3)(\mathrm{b})$.

$178 \S \S 30(3)$.

$179 \S 30(4)$.

$180 § 27(1)$.

${ }^{181}$ LMA $\S 28(1)$. note 150 , at 81 .

${ }^{183}$ See generally $\S \S 42-55$.

${ }^{184} \S \S 4-5$.
}

${ }^{182} \S \S 28(2)$, (3). Some marriages between Muslims are held privately, in contravention of the Act's requirements. This situation most often occurs when the bride is already with child, the couple has engaged in cohabitation, or when the parties are older Muslims who have been divorced or widowed. Bakari, supra 
they preside. ${ }^{185}$ In the case of customary marriage, the parties themselves must file for registration within thirty days after the ceremony. ${ }^{186}$ Upon granting an annulment or divorce, a court must send a copy of the decree to the Registrar-General, which is charged with keeping a database of such dissolved marriages. ${ }^{187}$

\section{e. Property Rights}

Married women are granted the same rights as men in acquiring, holding, and disposing of property. ${ }^{188}$ Each spouse retains separate rights in their property absent an agreement stipulating otherwise. ${ }^{189}$ Any property obtained in the name of one partner during the course of the marriage creates a rebuttable presumption that the property "belongs absolutely to that person, to the exclusion of his or her spouse."190 However, neither the husband nor the wife may unilaterally transfer rights in the matrimonial home without the other person's consent. ${ }^{191}$ Where such a prohibited transaction occurs, the other spouse retains the right to reside in the house as long as the marriage remains intact. $^{192}$

\section{f. Reconciliation, Divorce, and Division of Assets}

The LMA enshrines traditional concepts of informal dispute resolution prevalent in many African communities ${ }^{193}$ by establishing marriage conciliatory boards for each

\footnotetext{
$185 \S 43$.

$186 \S 45(5)$.

${ }^{187}$ LMA $\S \S 49-50$.

$188 \S 56$.

$189 \S 58$.

$190 \S 60$.

$191 \S 59(1)$.

$192 \& 59(2)$.

${ }^{193}$ See Rahmatian, supra note 141, at 303.
} 
ward. ${ }^{194}$ Courts must refrain from hearing a petition for divorce unless the couple has first referred the matter to one of these boards. ${ }^{195}$ The board hears testimony from both parties, neither of which may be represented by legal counsel, and conducts mediation in order to repair the couple's damaged relationship. ${ }^{196}$ If the board fails to bring to parties together, it will issue a certificate attesting to the failed reconciliation and may include it own recommendations regarding the dispute. ${ }^{197}$

When a court hears a petition for divorce, it looks to see if the marriage has deteriorated to an irreparable state in deciding whether to dissolve the union. ${ }^{198} \mathrm{~A}$ determination of marital breakdown will examine the totality of the circumstances surrounding the parties' relationship, with due regard given to the custom of the community to which the couple belongs. ${ }^{199}$ Evidence showing that a marriage has collapsed may include: adultery, ${ }^{200}$ "sexual perversion, ${ }^{, 201}$ cruelty, ${ }^{202}$ neglect, ${ }^{203}$ desertion, ${ }^{204}$ voluntary or judicial separation lasting for a period of at least three years, ${ }^{205}$ imprisonment ${ }^{206}$ or mental illness. ${ }^{207}$ Another relevant factor is if the respondent spouse changes faith and the laws of the religion formerly shared by both parties renders the

\footnotetext{
${ }^{194}$ LMA $\S \S 102$. Each board is comprised of three to six members, including a chairman. $\S 103$. It has been noted that the reconciliation process as adopted by the LMA is quite consistent with the marital dispute resolution provisions found in the Qur'an. Hashim, supra note 143, at 453.

${ }^{195} \S 101$. The reconciliation requirement will be waived where the petitioner can show that the other spouse is unable to appear, such as in cases of desertion, imprisonment, long-term absence from the jurisdiction, incurable mental illness, or other extraordinary circumstances. $\S \S 101(\mathrm{a})$-(f).

${ }^{196} \S \S 104(1),(8)$.

$197 \S \S \S 104(5),(6)$.

$198 § 99$.

$199 \S 107$. However, the board is precluded from issuing a decree if it finds that the petition for divorce is a result entirely of the petitioner's own wrongdoing. § 107(a).

${ }^{200}$ LMA $\S 107(2)(a)$.

${ }^{201} \S 107(2)(b)$.

$202 \S 107(2)(\mathrm{c})$.

${ }^{203} \S 107(2)(d)$.

${ }^{204} \S 107(2)(\mathrm{e})$.

$205 \S 107(2)(\mathrm{f})$.

${ }^{206}$ LMA $\S 107(2)(\mathrm{g})$.

${ }^{207} \S 107(2)(\mathrm{h})$.
} 
union dissolved. ${ }^{208}$ A special provision also applies to Muslim marriages, ${ }^{209}$ wherein courts will automatically accept as valid a divorce obtained according to Islamic law, provided that the board certifies that it was unable to foster reconciliation. ${ }^{210}$

Once a marriage is dissolved, the court has the power to divide assets jointly acquired by the couple during the course of the marriage. ${ }^{211}$ Two main factors the court considers in making this determination are the customary norms of the community to which the parties belong and the "contributions made by either party in money, property, or work towards the acquiring of the assets." ${ }^{, 212}$ This latter provision has proven to be contentious, as it does not specify what kinds of activities constitute work done in contribution to the accumulation of marital assets. ${ }^{213}$

\section{g. Maintenance and Child Custody}

Another novel development introduced into the Tanzanian legal system by the LMA is the availability of maintenance for women. ${ }^{214}$ Situations where a court may order a husband to make payments to his wife include: neglect, desertion, separation,

\footnotetext{
$208 \S 107(\mathrm{i})$.

$209 \S 103$.

${ }^{210}$ In this respect, the LMA specifically opens up the door for informal divorce by referring to "any act or thing which would, but for the provisions of this Act, have dissolved the marriage in accordance with the Islamic law." §107(3)(c). Andreas Rahmatian points out that this means that "virtually unadulterated Islamic divorce law is kept in the LMA." Rahmatian, supra note 141, at 298. The Shafi'i school of Islamic thought, which is prevalent in Tanzania, espouses an aversion to judicial intervention in dissolving marriages. Id; see infra note 327 for further discussion on the different strains of religious thought practiced throughout the country. In this respect, some commentators believe that the court system "acts merely as a 'clearing house' for the parties' actions." Makaramba, supra note 127, at 10. Nevertheless, in the absence of a divorce obtained under LMA $\S 107(3)$, the marital breakdown test will apply to dissolution procedures regardless of the parties' religious affiliations. See Abdallah Said v. Mwanamkuu Yusufu, [1978] T.L.R. 43, cited in Hashim, supra note 143, at 452.

${ }^{211} \S 114(1)$.

212 LMA $\S \S 114(2)(a),(b)$.

${ }^{213}$ Rose Mtengeti-Migiro, The Division of Matrimonial Property in Tanzania, 28 J. MODERN AFR. STUD. 521, 525, 522 (1990).

${ }^{214}$ Rahmatian, supra note 141 , at 300 ("This is a very satisfactory step, since such a rule is not founded in African legal traditions ....").
} 
divorce or during the course of any matrimonial proceedings. ${ }^{215}$ The determination is to take custom into account, as well as the degree of responsibility apportioned to each party for the breakdown of the marriage. ${ }^{216}$ Remarriage by either party extinguishes the right to maintenance. ${ }^{217}$

The guiding tenet in the awarding of child custody is the best interest of the child. $^{218}$ Whenever consistent with this principle, the court also takes into consideration the wishes of the parents, the child's desires, and the customs of the community to which the parents belong. ${ }^{219}$ However, the LMA creates a rebuttable presumption that "it is for the good" of a child under the age of seven to reside with his or her mother. ${ }^{220}$ Courts are not bound to award custody of all children to one parent. ${ }^{221}$ In the absence of an agreement between the parties, the father has a duty to maintain his children regardless of whether he has physical custody of them. ${ }^{222}$ If the father is dead, missing or otherwise unable to provide maintenance, the support obligation transfers to the mother. ${ }^{223}$

\section{Interpreting the Law of Marriage Act}

Several decades have elapsed since the enactment of the LMA, thus paving the way for a substantial body of law interpreting the Act's many provisions. While some cases have resolved ambiguities in the LMA and expanded certain legal rights, other decisions have exposed major gaps in the statute. The Court of Appeal's celebrated

\footnotetext{
$215 \S \S 115(\mathrm{a})-(\mathrm{e})$.

$216 \S 116$.

$217 \S 120$.

${ }^{218}$ LMA $\S 125(2)$ ("In deciding in whose custody an infant should be placed, the paramount consideration shall be the welfare of the infant ...").

${ }^{219} \S 125(2)(\mathrm{a})-(\mathrm{c})$.

$220 \S 125(3)$.

$221 \S 125(4)$

222 \& 129(1).

223 § 129(2).
} 
decision in Bi Hawa Mohamed v. Ally Seifu ${ }^{224}$ resolved a long-running split among lower courts as to whether women could claim housework and child care as contributions to jointly-acquired marital assets. ${ }^{225}$ In the 1971 case of Rukia Diwani Kinzi v. Abdalah Issa Kihenya, the High Court broadly read Section 114 of the LMA to include such efforts. ${ }^{226}$ A more conservative approach, which was adopted in the High Court's 1980 decision of Zawadi Abdallah v. Ibrahim Iddi, posited that a wife's domestic services did not factor into economic contributions because the LMA's drafters did not positively state otherwise. ${ }^{227}$ The Bi Hawa court declined to uphold the reasoning in Zawadi, which had relied on the original report issued by Kenya's Commission on the Law of Marriage and Divorce. Instead, the tribunal applied the mischief rule, which construes statutes based on the inequity that the legislation was designed to eliminate. ${ }^{228}$ Accordingly, the Court of Appeal held that the LMA was "an instrument of liberation and equality between the sexes" that sought to "cure or rectify was what may be described as the traditional exploitation and oppression of married women by their husbands. ${ }^{, 229}$ Therefore, Section 114 was read to include domestic services in determining the contribution of each party to familial wealth. ${ }^{230}$

The judiciary has taken generous approaches in other situations involving postdivorce remedies as well. In the 1991 case of Joseph Sindo v. Pasaka Mkondola, the High Court essentially ruled that cohabitants have the right to the same remedies

\footnotetext{
${ }^{224}$ [1983] T.L.R. 32, Court of Appeal (Dar es Salaam) Civ. App. No. 9 of 1983.

${ }^{225} \mathrm{Id}$. at 35-37.

${ }^{226}$ Matrimonial Cause No. 6 of 1971, quoted in Bi Hawa, [1983] T.L.R. 32, at 37.

${ }^{227}$ High Court Civil Appeal No. 9 of 1980, discussed in Bi Hawa, [1983] T.L.R. 32, at 35-36; see also LAW REFORM COMM'N OF TANZANIA, REPORT ON THE LAW OF MARRIAGE ACT 1971 2.3.1-2.3.2 (1994) [hereinafter LRC REPORT], available at http://www.lrct-tz.org/pdf/marriage.pdf; Hashim, supra note 143, at 455 .

${ }_{228}$ Bi Hawa, [1983] T.L.R. 32, at 43.

${ }^{229} \mathrm{Id}$. at 44 .

${ }^{230} I d$. at 45 .
} 
available to married couples upon dissolution of the relationship. ${ }^{231}$ By granting the female petitioner an equitable share of the couple's jointly-acquired assets, the High Court gave extra teeth to the LMA's presumption of marriage provisions. ${ }^{232}$ The later opinion of Halima Rashidi v. Amon Peter represented a significant advancement in the welfare of nonmarital children. ${ }^{233}$ In that 1993 decision, the High Court ruled that the best interests of the child standard should be applied in deciding custody even though the LMA's provisions technically did not cover the children of unmarried parents. ${ }^{234}$

Courts have also asserted the supremacy of the LMA in several cases where the Act's provisions potentially conflict with the rules of customary law or religious authority. In the 1990 case of Doitha Thuway v. Amathi Bura, the High Court found that cattle qualified as marital assets available for distribution to former wives, despite the fact that in some customary communities, land and livestock can only be passed on to direct descendents. ${ }^{235}$ A more recent High Court decision, Jonathan v. Republic, held that despite an accused rapist's assertion that his actions constituted a traditional marriage under customary norms, there cannot be a valid union without the woman's consent. ${ }^{236}$ The High Court also refused to enforce a Muslim conciliation board's award of 500,000 shillings as a parting gift to a woman divorced under Islamic law in Njobeka $v$.

\footnotetext{
${ }^{231}$ High Court Civil Appeal No. 132 of 1991, cited in Rwezaura, Building a New Family Law, supra note 137, at 529-30.

${ }^{232}$ Rwezaura, Building a New Family Law, supra note 137, at 530 (calling the Sindo case "a spectacular development of the law outside the walls of parliament" and noting that such a remedy was not even available to cohabitants in more socially progressive countries like Great Britain).

${ }^{233}$ High Court Civil Appeal No. 34 of 1993, cited in Rwezaura, Building a New Family Law, supra note 137 , at $535-36$.

${ }^{234} I d$. at 536.

${ }^{235}$ High Court Civil Appeal No. 9 of 1990, cited in Rwezaura, Building a New Family Law, supra note 137, at 527.

${ }^{236}$ High Court Criminal Appeal No. 53 of 2001, cited in Int'l Ass'n of Women Judges, Jurisprudence of Equality Program Decisions, http://www.iawj.org/jep/jep.asp (last visited May 12, 2006) [hereinafter IAWJ Cases].
} 
Mkogoro. ${ }^{237}$ According to the tribunal, the board's authority ended once reconciliation had failed; therefore, its recommendations were not binding and the primary court erred by not dividing the marital assets according to party contribution. ${ }^{238}$

One area in which case law has been unfavorable to women involves the property rights of co-wives in polygamous marriages. In Maryam Mbaraka Saleh v. Abood Saleh Abood, a senior co-wife was unsuccessful in reopening divorce proceedings involving her husband and a former co-wife. ${ }^{239}$ The ex-wife had won her case before the Court of Appeal, which held that she was entitled to forty percent of the marital property based on her contribution. ${ }^{240}$ The fact that the husband was engaged in a polygamous marriage was never brought up until the remaining co-wife sought to secure her share of the assets. ${ }^{241}$ Unfortunately, the Court of Appeal declined her request for relief on the grounds that she was not a party to the original divorce proceedings. ${ }^{242}$ However, even if the co-wife had been aware of this pitfall, she still would not have had much recourse, since remaining co-wives cannot be parties to divorce petitions. ${ }^{243}$ Thus, the court's ruling effectively gives divorcing co-wives a superior interest in matrimonial property. This gap in the LMA's provisions is surprising, as the Act "appears to contemplate only the divorce of couple who are monogamously married."244

\section{Reforming the Law of Marriage Act}

\footnotetext{
${ }^{237}$ High Court Civil Appeal No. 6 of 1991, cited in IAWJ Cases, supra note 188.

${ }^{238} \mathrm{Id}$.

${ }^{239}$ Court of Appeal of Tanzania Civ., Appeal No. 1 of 1992, cited in Rwezaura, Building a New Family Law, supra note 137, at 530.

${ }^{240}$ Rwezaura, Building a New Family Law, supra note 137, at 530.

${ }^{241} I d$. at 531 .

${ }^{242} \mathrm{Id}$.

${ }^{243} \mathrm{Id}$.

${ }^{244} I d$.
} 
While the LMA espouses "a policy inspired by caution, sensitivity and flexibility, ${ }^{, 245}$ the Act has attracted its share of criticism following its enactment. Just as organizations, such as the women's arm of the ruling party, Umoja wa Wanawake Tanzania (UWT), were instrumental in passing the LMA, ${ }^{246}$ these same groups have been dedicated to improving the Act by receiving complaints about various provisions that have been attacked as being ineffective or unfair. ${ }^{247}$ In 1986, the Law Reform Commission ("Commission") began reviewing the LMA, employing a variety of data collection methods, including hearings in local communities and the distribution of questionnaires to both experts and laypeople. ${ }^{248}$ The fruits of the Commission's efforts, the Report of the Law Reform Commission on Law of Marriage Act (No. 5, 1971), were finally presented eight years later to the Minister of Justice and Constitutional Affairs. ${ }^{249}$

One key area that the Commission targeted for reform is the treatment of marital property. After citing the successful implementation of separate property systems in other Commonwealth countries, the Commission identifies several problems created by the current Act, mainly the use of customary law in determining the division of property and the statute's failure to explicitly recognize housework and childcare as contributions to the acquisition of family assets. ${ }^{250}$ Regarding the former, the Commission notes that under some customary laws, women are categorically denied any share of property, while in other communities, the families of women blamed for causing marital breakdown must

\footnotetext{
${ }^{245}$ Rwezaura, Proposed Abolition, supra note 160, at 190.

${ }^{246}$ Rakstad et al., supra note 14, at 96-97.

${ }^{247}$ LRC REPORT 1.5.

${ }^{248} I d$. at 1.6-1.8, 4:0-5:0. The townhall-style public hearings were much more effective in eliciting input from the general populace than the written surveys. The Commission only had sixty-one responses to work with from the latter category. Id. at 6.2-6.3.

${ }^{249}$ Rwezaura, Proposed Abolition, supra note 160, at 187 n.1.

${ }^{250}$ LRC REPORT 1.11, 1.12.2, 2.8.
} 
repay the dowry. ${ }^{251}$ Because Tanzania's constitution provides for equal protection and prohibits "any law that is discriminatory either of itself or in its effect," the Commission recommends that references to customary law be struck from the LMA's provisions on marital property. Not only would this amendment bring the Act in line with constitutional principles but also fulfill Tanzania's obligations under the Convention of Elimination of All Forms of Discrimination Against Women ("Discrimination Convention") and the United Nations Convention on the Rights of the Child. ${ }^{252}$ Additionally, in light of the Bi Hawa decision, the Commission recommended that the LMA should be "amended to include wifely-duties of a house-wife as contribution enough to entitle her to a share of the family assets when the marriage breaks down." ${ }^{, 253}$

Another problem which the Commission addresses but offers no solution to is the difficulty of determining each party's ownership of individual property or contributions to particular pieces of property acquired jointly. ${ }^{254}$ The fact that most people do not possess written records of such transactions creates an impediment to the equitable division of assets. ${ }^{255}$ This is especially true for many households that are located in rural $\operatorname{areas}^{256}$ or where the woman is an unemployed housewife. ${ }^{257}$ Thus, even though $B i$ Hawa broadened the scope of contribution to family assets, "courts still are reluctant to

\footnotetext{
${ }^{251} I d$. at 2.8 .

${ }^{252} I d$. at 3.2 .

${ }^{253} \mathrm{Id}$. at 3.3.3. In the years following the Court of Appeal's opinion in Bi Hawa, concerns have remained that a more conservative panel of judges could later overturn the ruling. For example, in 1990, one commentator warned that Bi Hawa might only be a short-term gain for women as "the National Assembly has not yet intervened to make the Court of Appeal's decision 'water-tight." Mtengeti-Migiro, supra note 213, at 525, 526. However, subsequent cases, such as Bibie Mauridi v. Mohamed Ibrahimu, [1989] T.L.R. 162, have indeed followed Bi Hawa's reasoning. Id. at 456. Although the passage of time has enabled the principles set forth in Bi Hawa to become rooted in the legal landscape, there still is no statutory recognition of housework as a contribution to marital assets.

${ }^{254}$ LRC REPORT 1.12.1.

${ }^{255} \mathrm{Id}$.

${ }^{256} I d$.

${ }^{257}$ Id. at 1.8 .
} 
divide matrimonial properties equally and instead continue to give preferential treatment to the income-generating spouse who is usually the husband." 258 The inability of a wife to provide courts with tangible records, such as receipts, is a major issue. ${ }^{259}$

In the arena of child custody, the Commission criticized the practice of courts "tend[ing] to take as a mandatory rule" the rebuttable presumption that children under seven years old are better off living with their mothers. ${ }^{260}$ Such awarding of custody sidesteps a best interest of the child analysis, which is what the LMA mandates. ${ }^{261}$ On the other hand, the Commission also noted cases wherein the father of a child who is automatically placed with the mother "lays in waiting" and petitions for custody the moment the child turns seven. ${ }^{262}$ Rather than condoning the failure of courts to "have regard to the undesirability of disturbing the life of an infant by changes in custody," the Commission instead strongly encourages parents to enter into voluntary custody agreements as an alternative to court-imposed settlements. ${ }^{263}$ The goal behind this recommendation is to foster an amicable compromise between parents, thus sparing children from bitter familial disputes that impede the advancement of their best interests. ${ }^{264}$ However, the Commission makes one recommendation that may conflict with the principles mentioned above. Despite admonishing judges for glossing over the "best interest" test promulgated by the LMA in child custody cases, the report

\footnotetext{
${ }^{258}$ Rakstad et al., supra note 14, at 98.

${ }^{259} I d$.; LRC REPORT 1.8.

${ }^{260}$ LRC REPORT 4.6.

${ }^{261} I d$. at 4.7 ; LMA $\S 125(2)$.

${ }^{262}$ LRC REPORT 4.8.

${ }^{263} I d$. at 4.8-4.9.

${ }^{264}$ Id. at 4.10 .
} 
nevertheless proposes that in the absence of good cause, mothers should be awarded custody of children below fourteen years of age. ${ }^{265}$

The Commission has also identified several problems in the process of awarding maintenance. First of all, in the absence of any agreement stipulating otherwise, the LMA imposes on fathers the duty to maintain their children "whether they are in his custody or the custody of any other person, either by providing them with such accommodation, clothing, food and education as may be reasonable having regard to his means and station in life or by paying the cost thereof."266 No such obligation applies to mothers, who are responsible for maintenance only where the father is dead, missing or unable to provide the requisite support. ${ }^{267}$ The Commission criticized this disparity and proposed that the LMA be amended so that " $\mathrm{t}]$ he maintenance of a child must be a shared affair, where both parents are able and/or of means to pay." ${ }^{, 268}$ According to the Commission, the current maintenance obligations fail to adequately consider the mother's ability to pay. ${ }^{269}$ While such recommendations appear to advance the egalitarian spirit of the LMA, it is doubtful that their enactment would significantly impact the allocation of maintenance where the majority of women are of limited economic means.

In addition, the Commission found that the process of executing and enforcing court orders for maintenance was burdensome and inefficient. ${ }^{270}$ Courts may order maintenance payments to be made directly to the custodian (in most cases, the mother) or to the court. ${ }^{271}$ When the latter option is exercised, the receiving parent usually

\footnotetext{
${ }^{265} \mathrm{Id}$. at 6.1 .3 .

${ }^{266}$ LMA § 129(1).

${ }^{267}$ LMA § 129(2).

${ }^{268}$ LRC REPORT 6.1.4.

${ }^{269} \mathrm{Id}$. at 5.6

${ }^{270} \mathrm{Id}$. at 5.10, 6.1.5.

${ }^{271} \mathrm{Id}$. at 5.10.
} 
experiences long delays in obtaining payment. ${ }^{272}$ Although the court has the power to attach salaries in order to secure maintenance, employers do not act promptly in deducting sums from paychecks and delivering those funds to the court. ${ }^{273}$ Some employers even halt payments after receiving protests from the employee. ${ }^{274}$ As a result, the Commission issued a call for a "streamlining of the court's administrative section" so that maintenance could be paid more rapidly. ${ }^{275}$

The Act's prerequisites to marriage are also ripe for reform according to the Commission. For example, the twenty-one-day notice period was found to be too brief, especially in communities where the means of publicizing nuptials are rudimentary. ${ }^{276}$ Furthermore, parties have exploited the easy availability of special "emergency" licenses as a way to sidestep the notice requirement. ${ }^{277}$ In addition, registration requirements have been characterized as unnecessarily burdensome, especially in the context of customary law marriages. ${ }^{278}$ Again, this is an area where despite the LMA's policy of unifying the laws of marriage, not all unions are treated the same way. ${ }^{279}$ While kadhis and other ministers have the duty to register the marriages they solemnize, marriages contracted under customary law are oftentimes performed in remote locales that are not readily accessible to registration authorities. ${ }^{280}$ Because the obligation to register a marriage is placed on the parties if an officer is unable to attend the ceremony, "these marriages more

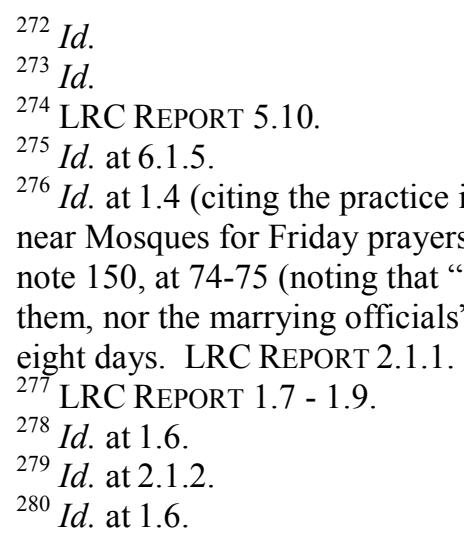
eight days. LRC REPORT 2.1.1.

${ }^{277}$ LRC REPORT 1.7 - 1.9.

${ }^{278} I d$. at 1.6.

${ }^{279} I d$. at 2.1.2.

${ }^{280} I d$. at 1.6. near Mosques for Friday prayers or at the village square or sometimes not at all"); see also Bakari, supra note 150, at 74-75 (noting that "[t]he majority of rural population being ignorant of the rules do not practise them, nor the marrying officials"). The Commission suggests that the notice period be increased to twenty- 
often than not become [a] secret affair, as far as the state authorities are concerned." 281

Consequently, the report suggests that customary law marriages be recorded as soon as they are performed and that each village have a designated secretary empowered to register marriages on the spot like a $k a d h i{ }^{282}$

Not surprisingly, the Commission set its sights on the LMA's minimum age requirements, which stand out as among the most visibly discriminatory provisions of the LMA. $^{283}$ Although it pointed out that the draft bill of the LMA as proposed by Government Paper No. 1 of 1969 was in line with international norms at the time it was released, ${ }^{284}$ the intervening years have brought many social and political changes that necessitate elimination of the provision creating different ages of consent based on gender. ${ }^{285}$ One main factor was the fact that the law considered fifteen-year-old girls capable of entering into a marriage covenant, which "has far reaching obligations than normal commercial contracts." ${ }^{, 286}$ Indeed, the age of capacity for all other legally-binding agreements is eighteen, as is the voting age. ${ }^{287}$ This inconsistency impacts girls who "may easily be coerced into a marriage by greedy parents and cause a lot of miseries to the girl in her married life." ${ }^{288}$ Furthermore, because a girl can marry at a young age,

\footnotetext{
${ }^{281} I d$. As evidence registration system's inability to deal with all forms marriages effectively, the Commission cited a continually widening gap between the registration of customary law marriages and marriages performed under civil, Christian, and Islamic rites. In fact, in the period covering 1983-84, there were more than seventy percent fewer customary law marriages recorded on the books than in the year following the LMA's enactment. Id. at 1.8.

${ }^{282}$ LRC REPORT 2.1.3.

${ }^{283}$ Id. at 1:0.

${ }^{284}$ Specifically, the white paper pointed to the UN's finding that in order to preserve the health of young women and their children, the minimum age of marriage for females should be fifteen. On the other hand, males were subjected to the higher minimum of eighteen years so as to ensure that young men finish primary school or acquire the requisite vocational skills to support a family. Id. at 1.2.

${ }^{285} I d$. at $1.3,1.4$. One preliminary consideration was Tanzania's accession to international conventions that "affect the thinking and outlook of the people towards women and children." Id. at 1.4.

${ }^{286} I d$. at 1.6.2.

${ }^{287} \mathrm{Id}$. at 1.6 .3 .

${ }^{288}$ LRC REPORT 1.6.5.
} 
those girls so affected are denied are the chance to complete higher education or acquire a trade. ${ }^{289}$ The Commission also cited "ample medical evidence" that "it is unhealthy and dangerous for a girl below the age of 20 years to give birth to children." ${ }^{290}$ Ultimately, the Commission recommended not only to apply the same age limit to both males and females, but also proposed that it be raised to twenty-one years. ${ }^{291}$ While this suggestion would laudably eliminate a major source of inequality in the Act, it curiously would also preserve the disparity in ages of majority for triggering various legal and political rights.

Despite receiving complaints regarding the marriage reconciliation boards, the Commission expressed its commitment to the LMA's dispute resolution regime, albeit with some changes. ${ }^{292}$ In an effort to ensure that female perspectives are incorporated into the procedure, the Commission proposed that the Act guarantee women representation on marriage conciliation boards. ${ }^{293}$ Furthermore, the report stressed that the purpose of these bodies is to repair marriages and therefore board members should refrain from assigning blame to any of parties. ${ }^{294}$ In the interest of processing disputes in a timely manner and minimizing hardship to the parties, the Commission called for cases

${ }^{289}$ Id. at 1.6.7.

${ }^{290} \mathrm{Id}$. at 1.6.1.

${ }^{291}$ Id. at 2.1.2.

${ }^{292} I d$. at 5:0-6:0.

${ }^{293}$ Id. at 6.1.3. The report does not elaborate as to what would constitute adequate representation, save for the caveat that "persons eligible for appointment to these Boards must be mature enough and not young men and women with no family experience in order to win the confidence of the parties with matrimonial difficulties before them." Id.

${ }^{294}$ LRC REPORT 6.1.4. This problem of finger-pointing has also arisen during actual divorce proceedings in court. Ulrike Wanitzek cites the 1993 High Court case of Tusajigwe Kambinda v. Edward Mwakikota, wherein the outcome of the decision hinged largely on the wife's alleged bad behavior, in spite of the fact that divorces are to be granted solely on the irreparable breakdown of the relationship. As such, "[i]t seems that once a wife falls short of the community's expectations, this, in itself, defines the wife as guilty, irrespective of what the law says," thus "reveal[ing] how the expectations of a good wife impacts on the mind of the court and ultimately on the rights of the woman litigant." Ulrike Wanitzek, The Power of Language in the Discourse on Women's Rights: Some Examples from Tanzania, 49 AFR. TODAY 3, 11 (2002). Nevertheless, the policy shift away from fault-finding to truth-gathering is reflected by the courts' adoption of an inquisitorial procedure rather than an adversarial one in divorce cases. Rahmatian, supra note 141 , at 299 . 
to be resolved within a period of six months ${ }^{295}$ and encouraged proceedings to be held in camera "as much as practicable." 296

While the bulk of the proposals advanced by the Commission involve the amendment of the LMA's existing provisions, the report's recommendation to delete the presumption of marriage stands out as the one instance where the Commission has advocated for the repeal of a reform originally ushered in by the Act. ${ }^{297}$ The Commission's vehement opposition to common law marriage is quite evident in the report's determination that "the presumption of marriage diminishes the sanctity of [the] marriage institution and [is] a mockery of those who marry according to established rites, religious or otherwise."298 Indeed, the report's otherwise dispassionate stance regarding religious issues became quite heated as the drafters wondered, "If the state wishes to protect [the] interest of children born out of [cohabitation] why it should not enact a law to facilitate such protection without referring [to] the sinful relationship between men and women as a marriage?"299

In a response to the report's avowed hostility towards the LMA's presumption of marriage, Professor Rwezaura, who served as a consultant to the Commission, ${ }^{300}$ issued a

\footnotetext{
${ }^{295}$ LRC REPORT 6.1.6. Andreas Rahmatian proposes that any mediation process should last for at least three months in order to cement a "durable reconciliation" and account for the period of $i d d a$ under Islamic law. Rahmatian, supra note 141, at 304.

${ }^{296}$ LRC REPORT 6.1.5.

${ }^{297} I d$. at 4.0 .

${ }^{298} \mathrm{Id}$. at 3.4.1.

${ }^{299} \mathrm{Id}$. at 3.4.3. The report's pointed question does draw attention to the fact that children born out of wedlock are insufficiently protected under the current legal system. The Commission did not seem to be too bothered by this state of affairs in its assertion that "De facto arrangements may be considered elsewhere such as in [the] Affiliation law and not in the LMA." Id. at 4.1.1; but see generally, Eugenne Mniwasa, Maintenance of 'illegitimate children' in Tanzania: A right or rhetoric? (2003) (unpublished essay, Univ. of Zimbabwe), available at http://www.uz.ac.zw/law/women/long\%20essays/Illegit\%20child.pdf (last visited May 10, 2006) (criticizing the Affiliation Ordinance as a measure that fails to secure adequate maintenance for the children of unmarried mothers).

${ }^{300}$ LRC REPORT INTRODUCTION 3.2.
} 
defense of Section $160,{ }^{301}$ noting the government recognition that the prevalence of de facto unions was already a social reality in Tanzania during the drafting the LMA. ${ }^{302}$ Furthermore, customary laws tend to treat marriage as "a process which is capable of completion over time," thus making it hard to determine an exact point at which such couples can be considered married. ${ }^{303}$ In other cases, men have acquired wives under customary law without notifying the woman that they are still married to another woman under civil or Christian rites. ${ }^{304}$ Thus, "Parties remain ignorant of their actual legal status under state law for a very long time - until one day a marital dispute or the death of one of the parties (especially the husband) throws a dark shadow on the validity of their marriage. $" 305$

In addition to providing some legal certainty to customary law relationships, Section 160 is a key component in advancing the LMA's goal of granting parties greater autonomy in contracting marriage and to mitigate the vulnerable position of nonmarital children. As to the first issue, the presumption of marriage allows couples to overcome the most significant socioeconomic hurdles to attaining an official marriage. ${ }^{306}$ Regarding the second concern, the informal nature of cohabitation makes important legal remedies difficult to obtain in the absence of certain recognized obligations on the part of

\footnotetext{
${ }^{301}$ See generally Rwezaura, Proposed Abolition, supra note 160.

${ }^{302} \mathrm{Id}$. at 187 . While acknowledging that lack of national statistics regarding the incidence of cohabitation in Tanzania, Rwezaura does cite a study completed in 1994 that relied on data gathered from a survey of Dar es Salaam residents. One main finding was that almost forty percent of the respondents were currently or at one point engaged in a de facto union. Id. at 191, 192.

${ }^{303} I d$. at $192,193-94$.

${ }^{304} \mathrm{Id}$. at 195 .

${ }^{305} I d$. at 196.

${ }^{306}$ Again citing the Dar es Salaam study, Rwezaura notes that "when [respondents were] asked why they had not gone through a formal marriage ceremony, $40 \%$ cited financial reasons, $28 \%$ said they belonged to different religions and 13\% cited parental objection to the proposed marriage." Id. at 203.
} 
parents. ${ }^{307}$ For example, "the lack of documentary evidence often provides an incentive to the parties to dispute the existence of marriage."308 As a result, women and children in particular would be put at an even greater disadvantage without Section 160, since it is "one of the few available means for [them] to access maintenance.",309

Despite Section 160's concerted effort to preserve accountability in de facto unions, one significant gap remains. Because the provisions only recognize presumptively valid (i.e., voidable) marriages, no statutory remedy exists for children born into void unions. ${ }^{310}$ The most prevalent example of this situation occurs when a women unwittingly cohabits with a man who is still legally married to another. ${ }^{311}$ Thus while a court is empowered to issue declaratory judgments examining the validity of a marriage, it does not have the jurisdiction to award maintenance or divide assets should that marriage be found invalid. ${ }^{312}$ This state of affairs, coupled with the fact that no mechanism is in place of "legitimizing" children, represents a violation of Article 2 of the United Nations Convention on the Rights of the Child, which prohibits against discrimination based on birth status. ${ }^{313}$ Nevertheless, Rwezaura makes a convincing argument that the baseline measures offered by the LMA should at the very least be maintained because "[f]or male cohabitants who wish to discard their partners, section 160 presents a nuisance to their notion of male hegemony and economic exploitations of females labour." 314

\footnotetext{
${ }^{307}$ Rwezaura, Proposed Abolition, supra note 160, at 204-06.

${ }^{308}$ Id. at 204.

${ }^{309}$ Id. at 205; see e.g., Rwezaura, Building a New Family Law, supra note 137, at 529-30 (discussing the Sindo case).

${ }^{310}$ Rwezaura, Proposed Abolition, supra note 160, at 205.

${ }^{311} \mathrm{Id}$.

${ }^{312} I d$.

${ }^{313} \mathrm{Id}$. at $206-07$.

${ }^{314} \mathrm{Id}$. at 212.
} 
Despite the Law Reform Commission's wide-ranging proposals for improving the LMA (notwithstanding its stance on de facto unions), the report fails to address other problem areas in the Act. For example, although the LMA provides that the absolute youngest age at which a couple may marry is fourteen (where either party is below the general minimum age and parental consent has been obtained), Section 138(6) of the Penal Code "states that 'any person of African or Asiatic descent' may 'marry or permit the marriage of a girl under the age of twelve years old in accordance with the custom of the tribe or religion, so long as it is not intended that the marriage be consummated before the girl is 12 years old.",315 In addition, marital rape is not a legally-recognized concept in Tanzania. ${ }^{316}$ As a result, child brides forced into sexual relations with their husbands may have no recourse under the law. ${ }^{317}$

Other commentators have identified ways in which the marriage dissolution process and awarding of post-marital remedies under the LMA can be reformed. The requirement that parties establish in court certain facts as evidence of marital breakdown has been characterized as superfluous because divorce proceedings are initiated only after a marriage conciliation board has already recognized the irreparable state of the union. ${ }^{318}$ Additionally, as previously mentioned, the LMA disadvantages co-wives who remain in a polygamous marriage by apparently granting a divorcing wife a superior interest in the

\footnotetext{
${ }^{315}$ EquALITY Now, EQUALITY NOW SUBMISSION TO THE UN HUMAN RigHTS COMMITTEE (1998), available at http://www.equalitynow.org/english/campaigns/un/unhrc_reports/unhrc_tanzania_en.pdf (last visited May 11, 2006).

316 The Sexual Offenses Special Provision Act of 1998 only recognizes spousal rape where non-consensual sex occurs between parties that have legally separated. CTR. FOR REPROD. LAW \& POLICY, WOMEN'S LEGAL Aid CTR., TANZANIA, WOMEN'S REPRODUCTIVE RIGHTS IN TANZANIA: A SHADOW REPORT 9 (1998), available at http://www.crlp.org/pdf/SRTanzania98en.pdf.

317 See Interview with Francis Stolla \& Anita Samwel Moshi, Tanganyika Law Society, in Dar es Salaam, Tanz. (Mar. 13, 2006).

${ }^{318}$ Rahmatian, supra note 141, at 306 ("the law should recognize the fact [of breakdown] and not protect perhaps an 'empty shell' of the marriage by taking into account whether the reasons for breaking up were fair or not").
} 
division of marital assets. ${ }^{319}$ Furthermore, it has been suggested that women should be automatically entitled to marital property and not have such protection be subject to the court's discretion. ${ }^{320}$

For all its flaws, the reforms ushered in by the LMA represent an important step in protecting the rights of women and children in Tanganyika and have elevated Tanzania as a model for other African nations. ${ }^{321}$ However, while the Act is certainly expansive in its scope, its provisions have been described as only a partial integration of family law in Tanganyika. ${ }^{322}$ This characterization is mostly attributed to the preservation of religious and customary law precepts for many aspects of marriage and divorce. ${ }^{323}$ For example, Muslims receive special treatment in that courts will automatically validate a divorce performed under Islamic law. ${ }^{324}$ Likewise, the Christian ideal of marriage is inscribed into the LMA by denying Christians the ability to contract into polygamous unions, an option which is available to other parties under the law. ${ }^{325}$ Indeed, the principle that "[t]he law should interfere with religious and customary practices as little as possible" has "prevented an entire unification of the marriage laws."

\section{B. The Law of Marriage and Divorce in Zanzibar}

\footnotetext{
${ }^{319}$ See Rwezaura, Building a New Family Law, supra note 137, at 532 ("It seems that the reason why the application of section 144 of the LMA to polygamously married couples leads to such unsatisfactory results is that the section was drafted without consideration of couples who are polygamously married.").

${ }^{320}$ Rakstad et al., supra note 14, at 104.

${ }^{321}$ Rahmatian, supra note 141, at 297.

${ }^{322} I d$. at 298.

${ }^{323} \mathrm{Id}$.

${ }^{324} I d$. at 297.

${ }^{325}$ Id.; Read, supra note 144, at 23.

${ }^{326}$ Rahmatian, supra note 141, at 298.
} 
The majority of one million Zanzibaris are $\mathrm{Muslim}^{327}$ and the remaining religions are Christianity, Hinduism and Zorathastrian. ${ }^{328}$ While Zanzibar does not have a purely

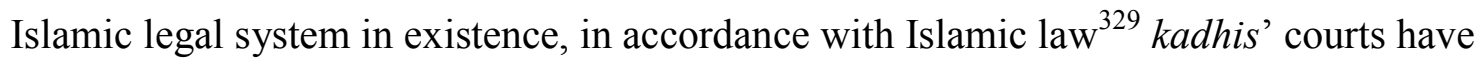
exclusive jurisdiction over Muslim cases concerning personal status, marriage, divorce, and inheritance. ${ }^{330}$ Due to the inherent nature of four schools and the absence of a uniform code, multiple interpretations of Islamic law have developed throughout the years resulting in a disparity between governance of Zanzibari Muslims. ${ }^{331}$ Furthermore, Zanzibar's separate family law system for Zanzibari Muslims delineates different rights in marriage and divorce from Zanzibari non-Muslims, Tanganyikan Muslims and Tanganyikan non-Muslims. ${ }^{332}$

\section{The Law of Marriage and Divorce for Muslims in Zanzibar}

\section{a. The Marriage Contract}

The legal structure for Muslim marriage and divorce is established in the

Qur'an. ${ }^{333}$ Muslim marriage regularizes sexual relations between men and women and

\footnotetext{
${ }^{327}$ Stiles, A Kadhi and His Court, supra note 1, at 3. Approximately 95\% of Zanzibaris are Muslim. There are a number of different schools of Islamic thought or madhhabs. Most people in Zanzibar follow the Shafi'i madhhab out of the four Sunni schools. It is the most prominent madhhab in East Africa. Even though the Omani Arab colonizers were Ibadhis, a few Zanzibaris still identify as Ibadhi. Additionally, a small community of Ismaili Bohra can be found in Zanzibar Town. Id.

${ }^{328}$ Situation Analysis For Women and Children in Zanzibar, Second Draft, The Government of Zanzibar and UNICEF, (2001) 19 [hereinafter Situation Analysis].

${ }^{329} \mathrm{Id}$. at 20 .

${ }^{330}$ Norrie, supra note 2, at 407; Background note: Released by the Bureau of Democracy, Human Rights and Labor, Feb. 28, 2005, available at http://www.unhcr.org/cgi-bin/texis/vtx/rsd/rsdocview.html [hereinafter Background Note].

${ }^{331}$ Situation Analysis supra note 328, at 20.

332 Stiles, A Kadhi and His Court, supra note 1, at 3; Background Note, supra note 330.

${ }^{333}$ Qur'an Suras 2:221-41; 4:3-35; 65:1-7, cited in SHAHLA HAERI, LAW OF DESIRE, TEMPORARY MARRIAGE IN SHI'I IRAN 25 (1989). Because the Qur'an (also spelled Koran) is unchanging, Islamic societies have historically opposed change in family law matters. Id.
} 
some extended definitions include expectations of children. ${ }^{334}$ Illustrating the role that Islam has in regulating the marital bond, the Prophet Muhammad proclaimed, “[m]arriage is my tradition,", 335 and that "[h]e who rejects my traditions is not my follower."336 Marriage thus bestows social prestige and religious merit for Muslims. ${ }^{337}$ Permanent marriage, nikah, is considered to be a contract of exchange with the $i j a b$, or offer, made by the woman or her guardian and the acceptance, qabul, made by the man, along with the payment of a dowry (also known as bride price), or $m a h r$, to the bride. ${ }^{338}$ The essence of the contract is a mutual understanding of these elements and full consenting capacity of the individuals. ${ }^{339}$ The contract is considered valid only with the presence of witnesses. ${ }^{340}$ In addition, a religious ceremony typically accompanies the

\footnotetext{
${ }^{334}$ DAVID PEARl \& Werner Menski, Muslim FAmily LAW 139 (1998). The Muslim marriage is slightly different than a Christian marriage in that it is not a sacrament. However, the marriage contract is a contract before God and thus has some religious obligations. Id. at 139-40. Any sexual contact outside marriage is prohibited and constitutes fornication, which is subject to heavy punishment. In addition, celibacy is condemned. ZIBA MIR-HOSSEINI, MARRIAGE ON TRIAL: A STUDY OF ISLAMIC FAMILY LAW 31 (1993). the sale of the bride to the husband. He does not have a right over her. However, he does have the right to access her sexually and her reproductive abilities. Id. at 32-3; HAERI, supra note 333, at 33. As a structural element, bride price cannot be eliminated from a marriage contract. Id. at 34 . According to some advocates, marriage contract terms can be specified by either party under Islamic law. For example, if the bride's parents insist that she finish schooling, they can include that provision in the contract. See Interview with Shifaa Said Hassan, Coordinator, Media Council of Tanz., in Stone Town, Zanzibar, Tanz. (Mar. 9, 2006); HAERI, supra note 333, at 38. The woman is expected in marriage to provide goods called, vyombo which are usually purchased by her parents with part of the dowry. These goods include things such as a bed, wash basins, and cooking pots, remain with the wife through marriage and divorce. Stiles, A Kadhi and His Court, supra note 1, at $271 \mathrm{n}$.3. In Zanzibar, bride price is also referred to as mahari. Id. at 108. It is common for parents to take the dowry if it is money, even though during the ceremony the money will be given personally to the bride. Situation Analysis supra note 328 at 33 .

${ }^{339}$ PEARL \& MENSKI, supra note 334, at 140-41. Under Islamic law, when a person has reached puberty, he or she has reached the age of majority and has the legal capacity to contract marriage. Id. However, some argue that a woman's consent to marriage is nullified by the fact that her father has the right to consent to her marriage. Interestingly, divorced and widowed women have more negotiation power and legal autonomy. HAERI, supra note 333, at 40.

${ }^{340}$ PEARL \& MENSKI, supra note 334, at 140.
} 
exchange. ${ }^{341}$ In most Muslim societies, these rituals are elaborate and constitute important rites of passage for the couple. ${ }^{342}$

Islamic law places limitations on Muslim women's ability to enter into interfaith marriages and polyandrous relationships. ${ }^{343}$ In contrast, under Islamic law, it is not objectionable for men to marry women of other faiths ${ }^{344}$ or to practice polygamy with up to four wives. ${ }^{345}$ Polygamy is permitted under certain circumstances along with the consent of the first wife. ${ }^{346}$ It can be practiced with the purpose of caring for orphans when a woman is widowed with children. ${ }^{347}$ Moreover, the husband should treat his wives equally with respect to support and maintenance. ${ }^{348}$ As a result of these restrictions, polygamy is usually either practiced in extreme situations or by wealthy Muslim men. ${ }^{349}$

Under the Marriage and Divorce Muslim Registration Act (Muslim Act), the parties to the marriage, the guardian of the woman, and two witnesses present at the ceremony appear before the kadhi within fourteen days of the celebration, provide pertinent information to the kadhi and sign the register. ${ }^{350}$ If the kadhi is satisfied that the marriage has been celebrated under Islamic law and the parties have correctly represented themselves, then he will register the marriage. ${ }^{351}$ In practice, anyone who passes an

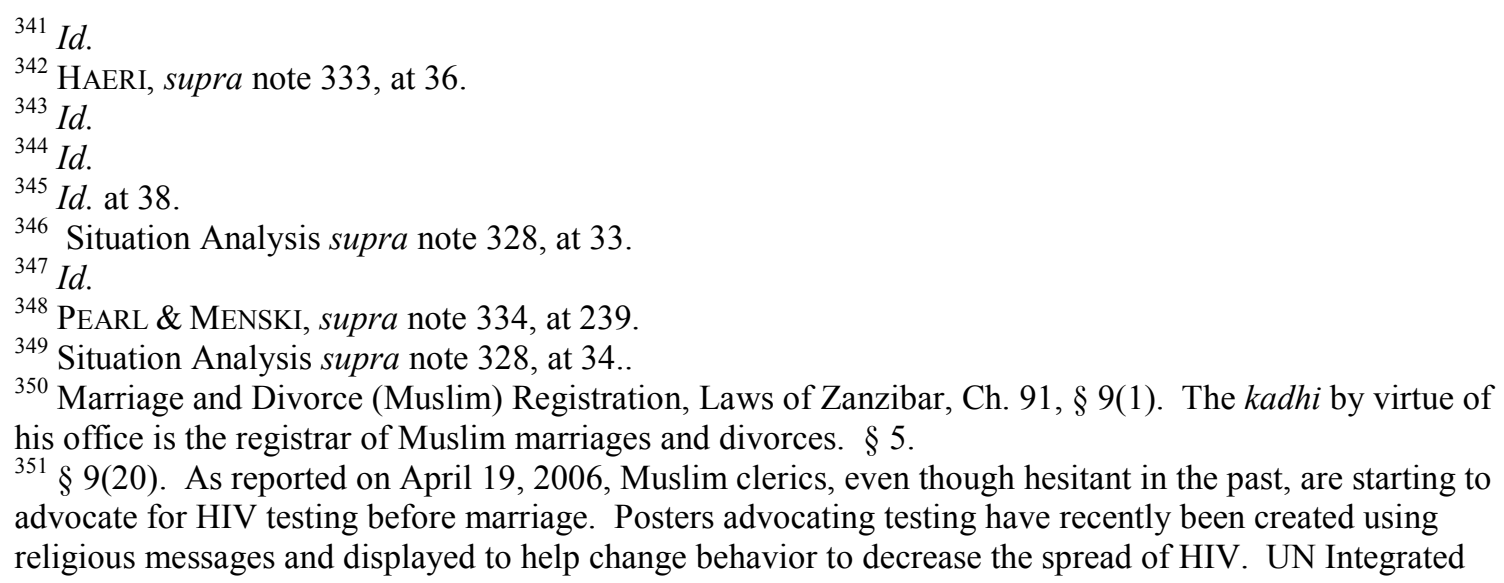
his office is the registrar of Muslim marriages and divorces. $\S 5$.

${ }^{351} \S 9(20)$. As reported on April 19, 2006, Muslim clerics, even though hesitant in the past, are starting to advocate for HIV testing before marriage. Posters advocating testing have recently been created using religious messages and displayed to help change behavior to decrease the spread of HIV. UN Integrated 
Islamic family law exam and receives a book of marriage certificates, can solemize a marriage. ${ }^{352}$

\section{b. Divorce}

For Zanzibari Muslims, there is a three-step process for resolving marital disputes. ${ }^{353}$ First, the couple must consult the family elders, the wazee. ${ }^{354}$ If the problem persists and the marriage cannot be mended, the matter is taken to the sheha. ${ }^{355}$ If the sheha fails, or if the problem is a complicated legal matter, the couple takes the sheha's referral letter to the state $k a d h i{ }^{356}$ The ultimate goal for some kadhis is to reconcile the couple, while for others, they see their sole function as applying religious law, assuming that the couple had already tried to repair the marriage with the efforts of the family elders and sheha ${ }^{357}$ Clerks of the kadhi's court prepare the madai, the plaintiff's claim with the plaintiff's approval. ${ }^{358}$ The court then issues a summons for the defendant and

\footnotetext{
Regional Information Networks, Zanzibar's Clerics Join Fight Against HIV/AIDs, Apr. 19, 2006, available at http://allafrica.com/stories.

${ }^{352}$ Stiles, A Kadhi and His Court, supra note 1, at 269-70.

${ }^{353} I d$. at 74. In Zanzibar, divorce is extremely common. Id. at 125.

${ }^{354} I d$. This is similar to the Conciliatory board where others assist in trying to repair the marriage. Usually family members who are respected come together to discuss the problem. Hassan, supra note 338.

${ }^{355}$ Stiles, A Kadhi and His Court, supra note 1, at 74. Shehas have had a role in local level dispute resolution well before the revolution and were chosen from their communities. After the revolution, the shehas were replaced with "chairmen." However, the shehas were reinstated by Act No. 11 of 1992, which amended the Local Government Act of 1986. The Act sets out numerous qualifications for the post and their responsibilities including, "settlement of all social and family disputes arising in that area in accordance with the customary laws of that area." Act No. 11 of 1992. Today, shehas tend to be supporters of the ruling party and are appointed by the government. Because they are elected by the government and not the community, shehas do not have the same reputation as they did in the past and are regarded with suspicion. Stiles, A Kadhi and His Court, supra note 1, at 76.

${ }^{356}$ Stiles, A Kadhi and His Court, supra note 1, at 76, 150. Others consult the local kadhi before opening a court case, however it is not a required step. Id. at 76 . The sheha's referral letter is necessary to open a divorce case in kadhi's court. If the couple has not seen a sheha, they are instructed to see one before returning to court. $I d$. at 150 .

${ }^{357} I d$. at 263 . Kadhis also distinguish between religious law, dini, state law, kanuni, and custom, mila. Some argue that customary law has not been codified in Zanzibar, however, some argue that it has been infused with Shafi'i Islamic legal ideas. $I d$. at 94 .

${ }^{358} I d$. at 150 . Clerks wield much power by essentially isolating the legal issues involved. Id.
} 
the defendant is given a chance to respond to the allegations. ${ }^{359}$ The parties are scheduled to appear together before the kadhi and they are presented with the opportunity to provide testimony and cross-examine each other. ${ }^{360}$ Witnesses may also be called to testify if there are discrepancies over essential facts of the case. ${ }^{361}$ Even though the Kadhi's Act requires that all witnesses, regardless of sex, be heard equally, ${ }^{362}$ one kadhi noted that a woman's testimony is considered worth only half that of a man. ${ }^{363}$ The parties can be called together to the court multiple times if necessary, but the parties appear before the kadhi in a final meeting when he delivers his judgment. ${ }^{364}$

Under the Marriage and Divorce (Muslim) Registration Act, if the kadhi is satisfied that the divorce is accurate under Islamic law and that the parties are who they claim to be, the kadhi will register the divorce, creating a rijista. ${ }^{365}$ A divorce is not final until it is officially registered with a kadhi's court and the kadhi issues a divorce certificate, or passi. ${ }^{366}$ The passi is an important document, as women are prohibited from remarrying unless the certificate has been presented to the marriage official. ${ }^{367}$ Depending on the situation, the kadhi can deny the divorce and mandate that the parties

\footnotetext{
${ }^{359} \mathrm{Id}$.

${ }^{360}$ Id. at 150-53; Marriage and Divorce (Muslim) Registration Act, Chapter 91, 1935 and 1936, amended 1944, § 10, (1). Before giving testimony, parties and witnesses swear in on the Qur'an. Stiles, A Kadhi and His Court, supra note 1, at 150-154.

${ }^{361}$ Stiles, A Kadhi and His Court, supra note 1, at 153.

${ }^{362}$ Kadhi's Court Act of 1985.

${ }^{363}$ Stiles, A Kadhi and His Court, supra note 1, at 154.

${ }^{364}$ Id.

${ }^{365}$ Marriage and Divorce (Muslim) Registration, Chapter 91, 1935 and 1936, amended 1944. at $§ 10$ (2). The only other requirement for an official divorce under the Divorce Act provides that divorces be registered with the kadhi's court within fourteen days of the pronouncement. Id. at $\S 5$. However, few talaq divorces are registered with the authorities within the allotted time period, if at all. Stiles, A Kadhi and His Court, supra note 1, at 269.

${ }^{366}$ Stiles, A Kadhi and His Court, supra note 1, at 76, 269.

${ }^{367}$ Id.
} 
remain married and work out their problems. ${ }^{368}$ If the litigants are not satisfied with the judgment, they can appeal within a month to the Chief Kadhi in Zanzibar Town. ${ }^{369}$

Because of the contractual nature of marriage under Islam, Islamic law specifically provides procedures for dissolving marital relations. ${ }^{370}$ Dissolution can occur under the following situations: 1) death of a partner; 2) repudiation of the wife by the husband, or talaq; 3) mutual consent, either through khul or mubarat; 4) annulment, also known as faskh; or 5) separation by court decree, or tatliq. ${ }^{371}$

The male spouse has the unilateral right to divorce. ${ }^{372}$ The husband can initiate a revocable, regular (talaq al-sunna) divorce or an irrevocable, irregular (talaq al-bid'a) divorce. ${ }^{373}$ A revocable divorce is a quasi-divorce where the contract of marriage is not completely dissolved. ${ }^{374}$ The husband and the wife remain separated for three months of purity and if the husband repudiated his wife three times during the this time, he completed the talaq. ${ }^{375}$ This form of divorce is considered a valid divorce. ${ }^{376}$ However,

\footnotetext{
${ }^{368}$ Hassan, supra note 338.

${ }^{369}$ Stiles, A Kadhi and His Court, supra note 1, at 76.

${ }^{370}$ HAERI, supra note 333, at 41. The Prophet Mohammad also said, "Of all things permissible, divorce, talaq, is the most reprehensible." Id. As a result, there is a stigma with divorce because the sanctity of marriage is so important to Muslims. Hassan, supra note 338; see also PEARL \& MENSKI, supra note 334, at 279.

${ }^{371}$ HAERI, supra note 333, at 41; MIR-HOSSEINI, supra note 334, at 36. Another type of divorce commonly referred to as "writing for money" is practiced in Zanzibar. A husband asks his wife for money when he divorces her without her request. This divorce is prohibited under Islamic law and is not recognized in Kadhis Courts. Stiles, A Kadhi and His Court, supra note 1, at 127.

${ }^{372}$ HAERI, supra note 333, at 42; Qur'an 2:226-37 and sura of Divorce. Talaq, meaning to let go or to untie a knot, is legally a unilateral act. Marriage is a form of contract based on mutual consent, whereas divorce is a unilateral right of the husband. There is a distinction between a contract of marriage and a contract of sale. "A contract of marriage is both irrevocable and revocable simultaneously." HAERI, supra note 333, at 42.

${ }^{373}$ HAERI, supra note 333, at 43; MIR-HOSSEINI, supra note 334, at 36.

${ }^{374} \mathrm{Id}$.

${ }^{375}$ MIR-HosSEINI, supra note 334, at 37. The three month waiting period is referred to as eda (also spelled, $e d d a, i d d a$, iddat). The wife must remain unmarried during this period. After eda period is over, she can remarry. The purpose is to confirm that she is not pregnant. If the husband and wife are living in the same house, they must sleep in different rooms. The husband is also required to provide for his wife during this period. However, this practice is not necessarily followed. Hassan, supra note 338. "When ye (men) put away women, put them away for the (legal) period and reckon the period, and keep your duty to Allah,
} 
if the husband returns to his wife during the three-month period and resumes his marital duties, then the talaq has not been fulfilled. ${ }^{377}$ The Prophet Muhammad limited this practice whereby a husband can divorce and return to his wife only twice. ${ }^{378}$ With a third revocable divorce, the husband is prohibited from returning to his wife. ${ }^{379}$

The husband can initiate an irrevocable divorce by oral pronouncement, written divorce or by action-driven divorce. ${ }^{380}$ When the husband pronounces orally that he divorces his wife three times, referred to as a triple divorce, the divorce takes legal effect. ${ }^{381}$ A pronouncement is typically worded in this manner, "I, Hussan Mohammad, am speaking in full mind, and you, Fatema Salah, are no longer my wife." ${ }^{382}$ This form of divorce requires the oral pronouncement be witnessed by two men under Islamic law. ${ }^{383}$ In other accounts, women are divorced without their knowledge and a third party, usually her parents, informs her. ${ }^{384}$ In such a case, formal proof is not available and the woman relies on oral testimony. ${ }^{385}$ When the pronouncement is made orally, many wives insist their husbands write down the talaq to establish credible evidence in the kadhi's court. ${ }^{386}$ In Zanzibar, the action-driven talaq is also practiced. ${ }^{387}$ A divorce driven by

your Lord. Expel them not from their houses nor let them go forth unless they commit open immorality." Qur'an, Sura 65:1.

${ }^{376}$ MIR-HosseINI, supra note 334, at 37.

${ }^{377} \mathrm{Id}$.

${ }^{378} I d$. at 44.

${ }^{379}$ HAERI, supra note 333, at 44. There is an exception, where a wife can marry another and divorce. Then she can remarry her original husband. However, the second marriage must be natural, not by blood.

Hassan, supra note 338.

${ }^{380}$ HAERI, supra note 333, at 44; Stiles, A Kadhi and His Court, supra note 1, at 275.

${ }^{381}$ Interview with Robert Makaramba, Lecturer, Univ. of Dar es Salaam, in Dar es Salaam, Tanz. (Mar. 7, 2006). The prophets look down on this type of divorce because there is no warning for the wife. Id.

${ }^{382}$ Interview with Betty Kinyenje, Att'y, Tanz. Crisis Ctr. (formerly TAMWA Crisis Ctr.), in Dar es Salaam, Tanz. (Mar. 13, 2006).

${ }^{383}$ MIR-HosseINI, supra note 334, at 37.

${ }^{384}$ Stiles, A Kadhi and His Court, supra note 1, at 269.

${ }^{385} \mathrm{Id}$.

${ }^{386}$ Hassan, supra note 338.

${ }^{387}$ Stiles, A Kadhi and His Court, supra note 1, at 275. 
action is when a husband prohibits his wife from performing an action and if she performs the action, she is divorced. ${ }^{388}$

Under Islamic law, the wife may not have a unilateral right to divorce, but she has the capacity to initiate divorce proceedings. ${ }^{389}$ She may obtain her freedom by paying an amount of money equal to, more or less, her brideprice. ${ }^{390}$ This option, known as khul, is not a unilateral right of women because it requires mutual consent of the husband. ${ }^{391}$ Even though $k h u l$ results in divorce, it is not equal to the unilateral right of talaq. ${ }^{392}$ In Zanzibar, khul divorces can be ordered by the court when a woman is found to be at fault for a failing marriage, which is usually indicative of her desire for a divorce, or if the wife refuses reconciliation. ${ }^{393}$ Additionally, if the husband and wife agree to mutually release one another, also referred to as mubarat, then their marriage can be dissolved. ${ }^{394}$

Lastly, a marriage can be dissolved by court decree, tatliq, or by annulment, faskh. ${ }^{395}$ Tatliq requires the intervention of the kadhi's court to declare the divorce on behalf of the wife or to compel the husband to pronounce a divorce. ${ }^{396}$ In Zanzibar, the wife typically goes to kadhis court with a complaint for maintenance during the marriage

\footnotetext{
${ }^{388} \mathrm{Id}$. at 275 . For example, if a woman is forbidden from sitting in a chair and she sits in the chair. She is then divorced. $I d$.

${ }^{389}$ HAERI, supra note 333, at 44. As it states in the Qur'an, “And it is not lawful for you that ye take from women aught of that which ye have given them . . . And if ye fear that they may not be able to keep the limits of Allah, in that case it is no sin for either of them if the woman ransom herself." Qur'an, 2:229.

${ }^{390}$ Id. Bride price becomes payable upon divorce. The main factor in determining bride price is whether or not consummation of the marriage took place. Whomever initiates the divorce usually pays the other. $I d$. at 43.

${ }^{391}$ HAERI, supra note 333 , at 44.

${ }^{392} \mathrm{Id}$. at 45. Also, a khul is an irrevocable divorce. Id.

${ }^{393}$ Stiles, A Kadhi and His Court, supra note 1, at 98.

${ }^{394}$ MIR-HOSSEINI, supra note 334, at 39.

${ }^{395} I d$.

${ }^{396}$ Id. While a kadhi can pronounce a divorce, he does not have the power to grant restraining orders against an abusive spouse. Restraining orders can only be obtained through the civil court system. Situational Analysis at 40.
} 
and the court essentially summons the husband. ${ }^{397}$ If he fails to appear, then the divorce is usually granted to the wife. ${ }^{398}$ If the husband appears, then the kadhi court can act as a mediator or it can grant the divorce, depending on the situation. ${ }^{399}$

From January 1, 1999 to July 15, 2000, the Mkokotoni court received 70 marital disputes, with $35 \%$ involving a disputed divorce. ${ }^{400}$ Shaykh Haji, the kadhi in Mkokotoni, looks beyond the husband's repudiation of his wife to certify the validity of a talaq divorce. ${ }^{401}$ He scrutinizes the circumstances surrounding the divorce, to ascertain if the proper intention motivated the action. ${ }^{402}$ Shafi'i legal texts such as Bughyat alMustarshidin suggest that intention plays a significant role. ${ }^{403}$ Shaykh Haji specifically looks at the meaning of the husband's words and actions. ${ }^{404}$ He listens to both the plaintiff's and the defendant's claims and deciphers the intentions behind the pronouncement, whether it be oral, written or by action. ${ }^{405} \mathrm{He}$ is in tune with the nuances of the situation. ${ }^{406}$ After reviewing the testimony, the kadhi will decide if the divorce is proven. $^{407}$

Most Zanzibari men utilize the written divorce pronouncement outside of court to initiate divorce. $^{408}$ An example of a written divorce pronouncement, which was held

${ }^{397}$ Hassan supra note 338.

${ }^{398} I d$.

${ }^{399}$ Id.

${ }^{400}$ Stiles, A Kadhi and His Court, supra note 1, at 273. From 2001-2002, the administrative officer at the Muftis Office in Zanzibar reported 240 cases of marriage conflicts. English Version Divorce Rate in Zanzibar, Tanz. Media Women's Ass'n, (on file with author).

${ }^{401}$ Stiles, A Kadhi and His Court, supra note 1, at 272-73.

${ }^{402} I d$.

${ }^{403} \mathrm{Id}$.

${ }^{404}$ Id.

${ }^{405} I d$. at 281 .

${ }^{406}$ Id.

${ }^{407}$ Id.

${ }^{408} I d$. at $276-80$. 
invalid, was submitted to the court by Abdulmalik, a thirty-year old male. ${ }^{409}$ His wife, Mariam, age nineteen was educated in religious matters and would often teach him after returning from the mosque. ${ }^{410}$ Mariam instructed Abdulmalik on how to divorce by advising him to write, "Mariam, you are no longer my wife" three times. ${ }^{411}$ Thereafter, Mariam claimed that they were divorced. ${ }^{412}$ Shaykh Haji ruled the divorce a nullity because Abdulmalik testified that he thought he was receiving religious education and had no intention of divorcing Mariam. ${ }^{413}$

Oral divorce pronouncements are also used by Zanzibari men, as long as the pronouncements are spoken in the presence of witnesses. ${ }^{414}$ One attempt at oral divorce was related earlier in the case of Shindano, the sixty year-old woman who was ordered to return to her husband. ${ }^{415}$ Under societal norms, her husband's rejection constituted divorce, however, under Islamic law the divorce was not fulfilled. ${ }^{416}$

While it remains an option, the action-driven divorce is rarely utilized. ${ }^{417}$ For example, Shaykh Haji heard a case where Leila, age thirty-two, sued for divorce from her husband, Bakari, age forty. ${ }^{418}$ In their marriage contract, Bakari was obligated to maintain Leila and it also required him to pay her 50,000 shillings (approximately $\$ 65$ USD) in back maintenance by a certain date. ${ }^{419}$ Because he was not able to uphold these

\footnotetext{
${ }^{409} \mathrm{Id}$.

${ }^{410} I d$.

${ }^{411} \mathrm{Id}$.

${ }^{412} \mathrm{Id}$.

${ }^{413} I d$. at $276-80$.

${ }^{414} I d$. at 287.

${ }^{415} \mathrm{Id}$. at 288-91; supra, Part I.

${ }^{416} \mathrm{Id}$.

${ }^{417}$ Stiles, A Kadhi and His Court, supra note 1, at 302-6.

${ }^{418}$ Id.

${ }^{419} \mathrm{Id}$.
} 
elements of the marriage contract, Leila claimed that she was divorced. ${ }^{420}$ Shaykh Haji found that the divorce was not in effect because Bakari had made a good faith effort to pay the back maintenance and more importantly, he had no intention of divorcing Leila. $^{421}$

\section{c. Property Rights}

Under Islamic law, women have equal rights with men in acquisition and disposal of property. ${ }^{422}$ This is evidenced from a woman's absolute property right to her mahr, or dowry, as she can give it away as she wishes. ${ }^{423}$ The Muslim religion assigns a duty to the husband to provide material means for the family. ${ }^{424}$ As the wife is not required to contribute to the family's maintenance, any of the wife's property or any income she may earn, however, is considered her own. ${ }^{425}$ Under Islamic law, joint marital property is nonexistent and therefore in divorce, a woman is limited to administering her own property. ${ }^{426}$ In Zanzibar, as a general rule, husbands and wives tend to keep their financial affairs separate. ${ }^{427}$ Where a house was acquired by the effort of both spouses, however, the High Court of Zanzibar has held that the property should be recognized as marital property and in the even of a divorce, should be divided between the spouses. ${ }^{428}$

\footnotetext{
${ }^{420} \mathrm{Id}$.

${ }^{421}$ Id. at 302-6.

422 Situation Analysis supra note 328 , at 44.

${ }^{423}$ PEARL \& MENSKI, supra note 334, at 185.

${ }^{424}$ Situation Analysis supra note 328, at 34. Because the husband has the duty to provide for the family, male children inherit a higher proportion than their female relatives under Islamic law. Id. at 20.

${ }^{425} \mathrm{Id}$.

${ }^{426}$ Erin Stiles, “There is No Stranger to Marriage Here!" Muslim Women and Divorce in Rural Zanzibar, 76 AFRICA (forthcoming Winter 2006) [hereinafter Stiles, “There is No Stranger to Marriage Here!'”]. Furthermore, in a polygamous marriage, if the husband passed away, the wife would inherit one portion, but larger portions are divided amongst the male children. Interview with Fatema Saleh \& Hamis Mmangea, State's Att'ys, Att'y Gen. Office, Zanzibar, in Stone Town, Zanzibar, Tanz. (Mar. 10, 2006).

${ }^{427}$ Situation Analysis supra note 328, at 34.

${ }^{428}$ Id. at 35 .
} 


\section{d. Maintenance and Child Custody}

Under Islamic law when the husband unilaterally divorces her, a Muslim wife has a right to maintenance during the eda period, which is three months. ${ }^{429}$ Interestingly, a husband can backdate a pronouncement by saying, "I divorce you since December 2001" to avoid paying the amount due throughout $e d a{ }^{430}$ After the three months, the husband is no longer obligated to maintain his ex-wife. ${ }^{431}$ In the strictest of sharia provisions, the wife is not entitled to anything beyond the dowry and if the marriage was consummated, she is entitled to maintenance during the eda period. ${ }^{432}$ However, all Muslim schools tend to agree that a consideration of socio-economic conditions, customs and traditions may influence the extent of maintenance. ${ }^{433}$

Under Islamic law, there is a distinction between physical custody and guardianship. Custody entails care and control of the child, whereas, guardianship deals with the legal rights and obligations of the child's father and representatives. ${ }^{434}$ Fathers generally have both custody and guardianship of their children. ${ }^{435}$ If a child is under the age of seven years, however, the child is placed in the physical custody of the mother. ${ }^{436}$ After age seven, the child returns to the father. ${ }^{437}$ Typically, Zanzibari women are afraid to return children to their remarried ex-husbands. ${ }^{438}$ Mothers are leery of stepmothers

\footnotetext{
${ }^{429}$ Saleh \& Mmangea, supra note 426; PEARL \& MENSKI, supra note 334, at 183; See also, supra FN 373 (regarding the purpose of $e d a$ ).

${ }^{430}$ Hassan, supra note 338.

${ }^{431} I d$.

${ }^{432}$ PEARL \& MENSKI, supra note 334, at 184.

${ }^{433} I d$. at 183 .

${ }^{434} I d$. at 410 .

${ }^{435} \mathrm{Id}$.

${ }^{436}$ PEARL \& MENSKI, supra note 334, at 411.

${ }^{437}$ Hassan, supra note 338 . If there is a dispute about where the child should live, the court can ask the child to choose. Situation Analysis, supra note 328, at 35. Shafi'i rules tend to allow for flexibility. In Egypt, for example, the mother has a right to custody of her son until he is ten years old and her daughter until she is twelve years old. PEARL \& MENSKI supra note 334, at 412.

${ }^{438}$ Hassan, supra note 338.
} 
because stepmothers rarely provide the same level of care that a mother provides. ${ }^{439}$

Divorced mothers may relinquish custody of children to their in-laws, if the in-laws show interest. $^{440}$ This option is uncommon due to the extra expense imposed on the grandparents. ${ }^{441}$ Nonetheless, it is the duty of the father to provide financial maintenance of his children until they are eighteen years old. ${ }^{442}$

\section{The Law of Marriage and Divorce for Non-Muslims in Zanzibar}

\section{a. The Marriage Contract}

Customary law, which is an amalgamation of approximately 120 types of tribal law, British Common law, and Indian law governs marriage among non-Muslims in Zanzibar. ${ }^{443}$ As previously discussed, the LMA was solely enacted in Tanganyika and its reach does not extend to Zanzibar. ${ }^{444}$ Although the majority of Zanzibaris are Muslims and thus subject to the tenets of Islamic law, the Marriage Solemnisation and Registration Act ("Marriage Act") also exists to govern civil marriage for individuals who do not subscribe to Islam. ${ }^{445}$ Under the Marriage Act, non-Muslims may marry, but are required to register with authorities. ${ }^{446}$ The statute requires one party to give notice in written form three months prior to or until the Registrar has granted the marriage. ${ }^{447}$ The notice is kept in a "Marriage Notice Book" and it is also posted in the Registrar's office. ${ }^{448}$

\footnotetext{
${ }^{439} I d$.

${ }^{440} I d$.

${ }^{441} I d$.

${ }^{442} I d$.

${ }^{443}$ Stiles, A Khadi and His Court, supra note 1, at 74; Background Note, supra note 330.

${ }^{444}$ Stiles, A Khadi and His Court, supra note 1, at 74.

${ }^{445}$ Zanzibar Marriage Solemnisation and Registration (Marriage Act), Cap. 92 (1915).

${ }^{446} I d$.

${ }^{447} \mathrm{Id}$. at $\S \S 6-7$. If a person is unable to write his name in English, then he may affix his mark in the presence of a witness who can explain the notice to him and his mark will be deemed a sufficient signature.
} 
A number of prerequisites must be satisfied before the Registrar may issue a marriage certificate: ${ }^{449}$ one of the parties must be a resident within the district in where the marriage is intended to take place at least fifteen days preceding the granting of the marriage; each of the parties to the intended marriage (not being a widower or widow) must be twenty-one years old, or if either of them is under that required age, parental consent must be provided in writing, ${ }^{450}$ close relatives or persons with lawful hindrances are prohibited from marriage; and parties who are currently married by native law or custom are prohibited from marrying. ${ }^{451}$

Once the Registrar is satisfied that the requirements to the marriage have been fulfilled and the fee is paid, ${ }^{452}$ the Registrar issues the marriage certificate. ${ }^{453}$ Marriages may be solemnized or celebrated in any licensed place of worship and must be signed by the minister and two witnesses. ${ }^{454}$ In the alternative, a marriage can be solemnized before the Registrar. ${ }^{455}$ Marriage for non-Muslims must be solemnized officially through the Registrar as the presumption of marriage or common law marriage is not recognized in Zanzibar. $^{456}$

$I d$. at $\S 6(2)$. Also, illiterate people can sign with thumbprints. Stiles, A Kadhi and His Court, supra note 14 at 269 .

448 Id.

${ }^{449} I d$. at $\S 9$.

${ }^{450} \mathrm{Id}$. Consent can be given by a father, or if he is dead or of unsound mind or absent, by the mother, or if both are dead or of unsound mind or absent, by the Protectorate. Id. § 16.

${ }^{451} I d$. at $\$ 9$.

${ }^{452} I d$. at $\$ 36$. The Registrar has the power to reduce or remit fees if the parties are unable to afford them.

${ }^{453} I d$, at $\S 8$. The marriage certificate can be issued any time after twenty-one days and before the expiration of the three months from the date the notice was submitted. Id. If the marriage does not take place within three months of the posting of the notice, all proceedings shall be void. $I d$. at $\S 10$.

${ }^{454} I d$. at $\S 5$.

${ }^{455} I d$. at $\S 23$.

${ }^{456}$ Saleh \& Mmangea, supra note 426. 


\section{b. Divorce}

Sparse information is available regarding the divorce procedures for non-Muslims in Zanzibar because the Marriage Act was codified in 1915 without a provision for divorce. $^{457}$ In a document prepared by the Government of Zanzibar and UNICEF in 2001, it states that, "Non Muslims cannot be divorced through the civil courts.",458 Under the Civil Procedure Code, one piece of legislation recognizes the right of action between a husband and wife for the "restitution of conjugal rights." 459 In injured spouse can seek a financial remedy if either spouse fails to comply with the order for restitution. $^{460}$

\section{c. Property Rights}

Women have equal rights to marital property. ${ }^{461}$ All property that is acquired during the course of the marriage is considered joint property. ${ }^{462}$ Both women and men hold individual rights to property owned prior to the marriage. ${ }^{463}$ As previously mentioned, the High Court of Zanzibar held in a divorce case that when both spouses made an effort to acquire property, the property was considered matrimonial property and was divided between the spouses. ${ }^{464}$ Unfortunately, few women are aware of this right. ${ }^{465}$

\section{d. Maintenance and Child Custody}

${ }^{457}$ Zanzibar Marriage Solemnisation and Registration (Marriage Act), Cap. 92 (1915).

${ }^{458}$ Situational Analysis, at 35.

${ }^{459}$ Women and Children in Zanzibar, a Review of the Law, Report to UNICEF Sub-Office, Zanzibar. Sept. 1997.

${ }^{460} I d$.

${ }^{461}$ Interview with Jilde Mambo, Att'y, Zanzibar Legal Services Ctr., in Wireless - Kisiwandui, Zanzibar, Tanz., (Mar. 9, 2006).

${ }^{462} I d$.

${ }^{463} \mathrm{Id}$.

${ }^{464}$ Situation Analysis, supra note 328, at 35.

${ }^{465} \mathrm{Id}$. 
The magistrate also decides other issues, such as, division of marital property, maintenance of the wife, custody of the children, and maintenance of the children. ${ }^{466}$ Even though little information is available as to the length of maintenance of the wife, child custody is determined by the court based on the habits of the mother. ${ }^{467}$ Court fees are not expensive, however, due to judicial corruption, a party has the ability to financially influence a judge. ${ }^{468}$ This injustice reduces the court's accessibility to women of lesser economic means. ${ }^{469}$ In addition, many Zanzibari women are typically unaware of their rights under Civil law. ${ }^{470}$ As a result of these problems, many non-Muslims divorce informally. ${ }^{471}$

\section{Special Provisions for Unwed Mothers and Nonmarital Children}

Reflecting the religious sentiment prevalent in Zanzibar, a special law directed against unwed mothers was enforced for until recently. ${ }^{472}$ Based on strong Islamic principles limiting sexual relations to within the marriage context, the Spinster Divorced Protection Act No. 4 ("Spinster Act”) of 1985 provided that if an unwed woman became pregnant, she was subject to imprisonment for two years. ${ }^{473}$ The mother was also restricted from returning to school after fulfilling her sentence. ${ }^{474}$ The father of the child could also be imprisoned for two years. Due to mounting criticism that the law punished

\footnotetext{
${ }^{466}$ Saleh \& Mmangea, supra note 423. Much discretion is left to the Magistrate judge. Id. ${ }^{467} \mathrm{Id}$.

${ }^{468} I d$. Also, independent observers continued to criticize the lower levels of the judiciary, as inefficient and corrupt. Background supra note 330 ("Clerks and magistrates took bribes . . . in opening cases and determining whether cases were judges as criminal or civil matters.”).

${ }_{469}^{40}$ Background Note, supra note 330.

${ }^{470} \mathrm{Id}$.

${ }^{471}$ Mambo, supra note 461.

${ }^{472}$ An Act to Repeal and Replace the Protection for Spinsters Decree and To Provide For Protection of Widows and Female Divorcees and to Provide For Other Matters Connected Therewith and To Provide For Other Matters Connected Therewith and Incidental Thereto, No. 4 (1985) (Zanzibar) [hereinafter Spinster Act].

${ }^{473} I d . \S 3(3)$.

${ }^{474} I d . \S 4$.
} 
illegitimate children by forcing them to be born in prison, the statute was repealed in 2005 and replaced with the Spinsters and Single Parent Children Protection Act of 2005. ${ }^{475}$ Unwed mothers are no longer imprisoned, but are still required to perform community service starting three months after the child's delivery. ${ }^{476}$ The mother serves the community for a total of six months and she is entitled to be reinstated in school the next academic year. ${ }^{477}$ If the father of the child is under the age of eighteen, he can also be required to perform community service. ${ }^{478}$ Furthermore, males that are proven or alleged to be the father of a nonmarital child have the duty to provide maintenance for that child. ${ }^{479}$

\section{RESPONDING TO LEGAL PLURALISM}

As the previous section has outlined, Tanzania's system of multicultural accommodation results in vastly different sets of rights that are available to individuals in marriage and divorce based on geography, religion, and customary community affiliation. In almost all cases, women are the ones who are disadvantaged by the inequalities enshrined in the various legal orders accommodated by the state. While it is clear that existing laws should be amended to protect the legal rights of women, the complex dynamics inherent in a pluralist, postcolonial society such as Tanzania call for a sensitive approach to reform that is attenuated to the interests of all parties involved.

For those wishing to advance the rights of women in the face of discriminatory cultural practices, a few considerations must be taken into account. For example, a

\footnotetext{
${ }^{475}$ The Spinsters and Single Parent Children Protection Act, No. 4 (2005) (Zanzibar).

${ }^{476} I d . \S 3(6)$.

${ }^{477} I d . \S 4(2)$.

${ }^{478} I d . \S 3(5)$.

${ }^{479} I d . \S 8(1)$.
} 
heavy-handed imposition of majority values upon a community may drive that community to adopt stricter interpretations of its cultural traditions in response to perceived assaults from the outside world. ${ }^{480}$ Indeed, "when people's identity is attacked or demeaned, they often react by clinging to it ever more fiercely." as Shachar, this so-called "reactive culturalism" 482 represents a kind of "political crisis" ${ }^{483}$ wherein well-intentioned attempts to protect women can actually place those vulnerable individuals in a worse position socially and legally. ${ }^{484}$

Furthermore, outside observers, especially those espousing secular feminist perspectives, oftentimes dismiss religious traditions as merely a source of oppression and ignore the role of those beliefs as a source of cultural meaning and social cohesion in the lives of many women. ${ }^{485}$ Indeed, religion can be such an integral part to self-identity that "women who belong to religious groups that suffer discrimination or that feel besieged because of their minority position would be unwilling to undermine their communities by making public collective feminist demands in concert with women not members of their own community." ${ }^{486}$ Referring to Jewish and Muslim women as an example, Rhoda Howard-Hassman suggests that "women [in those communities] might very well decide that they would rather not wash their dirty linen in public.."487 In other words, an

\footnotetext{
${ }^{480}$ See, e.g., Gary Yonge, How to fight reactionaries, GUARDIAN WEEKLY, Aug. 25, 2006, available at $\mathrm{http}: / /$ www.guardian.co.uk/guardianweekly/story/0,,1856601,00.html.

${ }^{481}$ Spinner-Halev, supra note 47, at 96.

${ }^{482}$ SHACHAR, MUlTiCULTURAL JURISDiCTIONS, supra note 3, at 35.

${ }^{483}$ See Christina L. Brandt-Young, Multicultural Jurisdictions at the National and International Levels, 24 MiCH. J. INT'L L. 241, 252 (2002) (reviewing SHACHAR, MULTICULTURAL JURISDICTIONS, supra note 3).

${ }^{484}$ See, e.g., Shah Bano and related discussion, supra Part II.

${ }^{485}$ See Preston, supra note 32, at 199-200. Rhoda Howard-Hassman also points out that in asserting their interests, women may not necessarily identify themselves primarily as women, but rather in terms of other affiliations, such as ethnicity, religion, and occupation. Symposium, Dueling Fates: Should the

International Legal Regime Accept a Collective or Individual Paradigm to Protect Women's Rights?, 24

Mich. J. Int' L. 347, 381-82 (2002).

${ }^{486} I d$. at 386.

${ }^{487}$ Id.
} 
uncompromising antagonism towards religion can be counterproductive, as its forces women to choose between individual rights and spiritual or social belonging. ${ }^{488}$

For these reasons, in addition to those mentioned earlier, ${ }^{489}$ a purely abolitionist approach would be an inappropriate response to legal pluralism in light of the complex dynamics inherent in a multicultural, postcolonial populace. Reformation of discriminatory cultural practices should thus stem from genuine internal transformation, lest overt coercion by outside forces be met with resistance from the community itself. While the process of social change is a difficult project fraught with many challenges, "[i]f incentive structures change, cultural identities, practices, patterns, and meanings can be quite fluid, flexible, and open to transformation or reinvention. ${ }^{, 490}$ Despite the portrayal of traditional cultures as monolithic and unchanging, experience has shown that the constituent beliefs and practices are open to negotiation where circumstances necessitate or encourage it. ${ }^{491}$ Islamic family law, for instance, has been subject to multiple interpretations around the world, which has resulted in varying conceptions of rights and duties across different Islamic nations and societies. While Islamic law as applied to Muslim communities in Tanzania and India permits polygamy, the practice has been outlawed or severely limited in states like Tunisia and Morocco, where the overwhelming majority of the population are Muslims. ${ }^{492}$

\footnotetext{
${ }^{488}$ See Preston, supra note 32, at 199-200; Elisabeth Schussler Fiorenza, Public Discourse, Religion, and Wo/men's Struggles for Justice, 51 DEPAUL L. REV. 1077, 1084 (2002), quoting Farida Shaheed, The Cultural Articulation of Patriarchy: Legal Systems, Islam, and Wo/men, 6 S. ASIA BULl. 43 (1986).

${ }^{489}$ Part II, supra.

490 Tripp, supra note 4 , at 417.

${ }^{491} I d$. at $427-34$.

${ }^{492}$ See LMA § 10(1); Jain, supra note 5, at 220; Bharathi Anandhi Venkatraman, Islamic States and the United Nations Convention on the Elimination of All Forms of Discrimination Against Women: Are the Shari' $a$ and the Convention Compatible?, 44 AM. U.L. REV. 1949, 1980-81 (1995); Ilhem Rachidi, After struggle, new equality for Moroccan women, CHRISTIAN SCIENCE MONITOR, Oct. 24, 2003, available at http://www.csmonitor.com/2003/1024/p09s01-wome.htm.
} 


\section{A. The "Transformative Accommodation" Model of Joint Governance}

In deciding how much autonomy to allocate to accommodated communities, policymakers need to pursue mediated measures that balance the group rights and individual liberties. ${ }^{493}$ Gordon Woodman's concept of "selective legal pluralism" represents one such compromise, which involves "purposeful intrusion by the state into customary law fields, ground in principle with reference to each set of particular circumstances." ${ }^{494}$ Likewise, Brenda Oppermann maintains that "[s]ince traditional law is an integral and valuable element of many legally pluralistic societies, it need not be wholly renounced because of its discriminatory aspects." ${ }^{495}$ However, where customary and religious law conflicts with recognized international human rights standards or ignores the legal protections guaranteed by national constitutions, those discriminatory provisions should be overridden. ${ }^{496}$ As Shachar points out, "[i]f the contemporary multicultural state hopes to provide relief to citizens whose rights are violated by their groups' traditions, then theorists and legislators must recognize that the state should not fully relinquish its power over identity groups." ${ }^{497}$

If one begins with this premise that state intervention into group autonomy is warranted in certain situations, Shachar's paradigm of joint governance is an illuminating

\footnotetext{
${ }^{493}$ See Stone, supra note 34, at 1224 ("Multiculturalism is a needed corrective to the hubris of liberal universalism. Both perspectives are necessary, however").

${ }^{494}$ Woodman, supra note 15 , at 166 . Some feminists scholars have advanced the idea that state "intrusion" into the "private" sphere of family relations is a fallacy since " $[\mathrm{t}]$ he family is created and the power structures in it are maintained by constant intervention of the state through laws that determine the structure of the family and what rights and duties family members have toward each other." Stopler, supra note 32 , at 216 .

${ }^{495}$ Oppermann, supra note 7 , at 91 .

${ }^{496}$ Id. at 92.

${ }^{497}$ Shachar, Group Identity and Women's Rights, supra note 7, at 296.
} 
example of how to negotiate the complexities of legal pluralism. ${ }^{498}$ In the context of family law, religious and cultural communities, or nomoi groups, ${ }^{499}$ would have the ability to police their own boundaries since it is a function that is essential to group identity. ${ }^{500}$ Such jurisdiction would include "among other things, who can become a group member through marriage, and under which conditions divorced group members can marry within the faith and have children who will be considered full and legitimate members of the community." ${ }^{501}$ On the other hand, the state would have the power over issues like alimony, property division, and child support because those "are not concerns unique to group members" since "[a]11 state citizens potentially face similar dispute when dissolving marriage." 502 Thus, the state can and should apply uniform laws to deal with issues that do not directly implicate the integrity of a particular nomoi group. ${ }^{503}$

Thus, Shachar's conception of joint governance, or 'transformative accommodation," embodies three main elements. ${ }^{504}$ First, contested social arenas, such as family law, are to be divided into "sub-matters," with jurisdiction allocated along submatter lines. ${ }^{505}$ The second element, which is closely related to the first, posits a "no monopoly" rule that ensures that neither the state nor the individual nomoi group wields exclusive authority over a particular social arena. ${ }^{506}$ Third, individual members of a

\footnotetext{
${ }^{498} I d$. at 300 .

${ }^{499}$ SHACHAR, MULTICULTURAL JURISDiCTIONS, supra note 3, at 2.

${ }^{500}$ Shachar, Group Identity and Women's Rights, supra note 7, at 300.

${ }^{501} I d$.

${ }^{502} I d$.

${ }^{503}$ Thus while multiculturalist policies of accommodation may serve as a corrective to past inequities that disadvantaged certain nomoi groups, see supra note 24 , "minority claims that then go further to stipulate that another group may be deprived of its rights, for example, women or another religious or ethnic group, cannot be seen as essential any particular group's effort to equalize the score .... We know that suppression of women's rights is not essential to the uniqueness of a particular group because cultures have always been variable." Tripp, supra note 4, at 419 .

${ }^{504}$ SHACHAR, MULTICULTURAL JURISDICTIONS, supra note 3, at 118.

${ }^{505} \mathrm{Id}$. at $119-20$.

${ }^{506} I d$. at $120-22$.
} 
nomoi group must be given clearly delineated choice options in deciding whether to invoke the jurisdiction of the state over the nomoi group should the nomoi group fail to adequately protect the interests of the individual. ${ }^{507}$ While jurisdiction primarily lies with the nomoi group, this final element of transformative accommodation allows members to opt-out of group authority in the face of oppressive treatment. ${ }^{508}$ The state should thus act as the ultimate guarantor of equality by relying on the individual rights granted by national constitutions and statutes, as well as applicable international conventions. ${ }^{509}$ Shachar concludes that the existence of state jurisdiction as a competitive choice option creates an incentive for group leaders to respond to the needs of vulnerable constituents or else risk losing dissatisfied members. ${ }^{510}$

\section{B. Joint Governance, Legal Pluralism, and the Tanzanian Experience}

To a great extent, a system of joint governance in family law has already been established for most Tanzanians. This has been achieved in the form of the Law of Marriage Act in Tanganyika. While jurisdiction over matters of personal status remains with the various religious and customary communities within Tanzania, the state has applied uniform provisions over matters such as consent, brideprice, registration, custody, and maintenance. The Act has thus been a welcome development for judges as well as litigants faced with the task of navigating Tanzania's pluralist legal system. Furthermore, nonmarital children have received increased protection through the presumption of

\footnotetext{
${ }^{507}$ Id. at $122-26$.

${ }^{508} I d$. at $123-24$.

${ }^{509}$ See, e.g., Shachar, Group Identity and Women's Rights, supra note 7, at 301 (discussing the Israeli Supreme Court case of Bavli v Rabbinical High Court, which in overruling a rabbinical court's allocation of marital assets, acknowledged that while religious communities have jurisdiction over the status of their members, the state's jurisdiction controlled over property issues in connection with divorce).

${ }^{510}$ SHACHAR, MULTICULTURAL JURISDICTIONS, supra note 3, at 140-141.
} 
marriage established by Section 160 of the LMA. Consequently, the LMA represents a significant step in securing the equality of women under the law.

Nevertheless, as the Law Reform Commission and other observers have pointed out, there are areas of marriage and divorce law where Tanganyikans receive discriminatory treatment either directly under the provisions of the LMA itself or through the undue discretion given to customary and religious communities by the Act to regulate certain issues. A primary example is the continued application of customary law to issues of marital property, which can result in women being denied an equitable share of marital assets upon dissolution of marriage. Furthermore, the LMA does not officially recognize domestic work as a contribution to marital assets even though the Bi Hawa decision has set a precedent for courts to decide otherwise in the division of marital property. Additionally, the LMA sets the marriage age at eighteen for males, yet girls may be married off as young as fifteen. Even this already limited protection for girls is further reduced by the Penal Code's loophole that permits the marriage of girls under twelve if pursuant to religious or tribal custom. This law sidesteps the uniform age provisions of the LMA and offers no remedy for child-brides who are forced into sexual relations with their husbands.

In Zanzibar, where there is no uniform law of marriage, the religious and customary traditions have a near monopoly over important issues of family law, unlike in Tanganyika. The kinds of reforms that have generally benefited Tanganyikans of all religions via the LMA are unavailable to Muslims in Zanzibar. Because Muslims make up the vast majority of Zanzibaris, there are no opportunities for individuals born into Muslim communities to opt out of Islamic law in favor of state jurisdiction over areas 
such as divorce, division of marital property, child custody, and maintenance. For the small fraction of Zanzibaris who are not Muslim, ${ }^{511}$ there are not even any official statutes to regulate divorce, maintenance, and child custody. In a positive move, however, Zanzibar's lawmakers have tempered the harsh provisions of the old Spinster Act by replacing it with the Spinster and Single Parent Children Protection Act, which while still punitive in nature, spares nonmarital children the burden of being born in prison. Furthermore, the law also provides maintenance to children conceived outside of marriage.

Certain applications of Islamic law also create disadvantages for women. For example, Muslim women do not have the same unilateral right to pronounce a divorce as a Muslim man and can only seek a divorce with the consent of her husband or the kadhi's court. Moreover, Muslim women are required to respect eda and wait three months after a divorce before they can remarry. Muslim men, on the other hand, do not have such a restriction. Also, even though women have to right to own property under Islamic law, they do not have to right to joint property in marriage. ${ }^{512}$ Again, while the LMA has taken limited steps to regulate distributive aspects of marriage and divorce law, these measures are inapplicable to women living in Zanzibar.

Another area ripe for debate is the continued sanction of polygamy by the state in Tanzania. Current laws and the traditions they accommodate provide only men with the right to possess multiple spouses. Neither the secular law of the LMA nor the religious laws applicable to communities in both Tanganyika and Zanzibar permit polyandry. While this discrepancy may simply reflect the cultural logic of Tanzanian society, the

\footnotetext{
${ }^{511}$ Non-Muslims account for approximately one percent of Zanzibar's population. Tanzania, The World Fact Book, available at http://www.cia.gov/cia/publications/factbook/geos/tz.html\#People.

${ }^{512}$ Stiles, supra note 22; Saleh \& Mmangea, supra note 426.
} 
discriminatory treatment of women under the law is quite apparent. Women in Tanganyika, however, do have a greater degree of autonomy because the LMA grants them the ability to veto their husband's marriage to a new wife. Unfortunately, the LMA also fails to take in account the property interests of co-wives at divorce, as illustrated by the Saleh decision.

Of course, such concerns over the denial of the right to polyandry and the property rights of co-wives are relatively minor in the face of arguments calling for the prohibition of polygamy altogether. ${ }^{513}$ Again, while attempts by the state to abolish cultural practices must take into account the potential for reactive culturalism, it should be noted that reform can indeed be effected if properly framed within local traditions. For example, proponents of the ban on polygamy in Tunisia based their arguments on passages from the Qur'an, which appears to acknowledge the inequalities inherent in polygamous relationships. ${ }^{514}$ Similarly, recent changes to the family law in Morocco carefully invoked religious authority to ensure the credibility of the proposed reforms. ${ }^{515}$ Indeed, a reflection of changing attitudes towards polygamy in the African context can already be found in the Draft Protocol to the African Charter on Human and Peoples' Rights on the Rights of Women in Africa (Draft Women's Protocol), which calls for an end to the practice. ${ }^{516}$

\footnotetext{
${ }^{513}$ The main objections to polygamy involve the disproportionate balance of power that husbands have over their wives. On the other hand, there are also various historical and economic reasons that support this type of domestic arrangement. See Rhoda Howard, Women's Rights in English-Speaking Sub-Saharan Africa, in Human Rights AND DeVElopment In AFRICA 60-61 (Claude E. Welch, Jr. \& Ronald I. Meltzer eds., 1984).

${ }^{514}$ Venkatraman, supra note 492, at 1980-81.

${ }^{515}$ Rachidi, supra note 492.

${ }^{516}$ Organisation of African Unity (OAU) Doc CAB/LEG/66.6 of (Sept. 13, 2000); cited in Martin Semalulu Nsibirwa, A Brief Analysis of the Draft Protocol to the African Charter on Human and Peoples' Rights on the Rights of Women, 1 AFR. HUM. RTS. L.J. 40, 46 (2001). Nevertheless, the polygamy clause hinders the adoption of the Draft Protocol because many members of the OAU have large Muslim populations. Id.
} 
Tanzania's unique political arrangement thus results in multiple layers of legal pluralism that provide for different rights and duties based on gender, religion, custom, and geography. A Muslim woman may not only receive different legal treatment than her Christian neighbor, but may also assert more freedoms than a fellow Muslim living in another part of the country. While this result is not necessarily objectionable under a multiculturalist theory of justice, more recent understandings of multicultural accommodation recognize the need to provide vulnerable individuals the option of invoking state jurisdiction where the nomoi group fails to protect individual rights.

In Tanzania, the state's authority to secure equitable treatment of citizens already has a basis in several sources of domestic and international law. Article 29(1) of the Constitution of Tanzania provides that "[e]very person in the United Republic has the right to equal protection under the laws of the United Republic." ${ }^{\text {517 }}$ Section 4 further states, "[i]t is hereby prohibited for any law to confer any right, status, or special position upon any citizen of the United Republic on the basis of lineage, tradition or descent." More specifically, the Constitution charges the state authority and all its agencies to provide equal opportunities to all citizens without regard to their religion. ${ }^{519}$ In regard to gender, Article 9(1)(g) states, "the Government and all its instruments of the people offer equal opportunities for all citizens, men and women, regardless of color, tribe, religion or creed." ${ }^{520}$ Nevertheless, because this provision was included under the section, "Fundamental Objectives and Directive Principles of State Policy," the scope of the

\footnotetext{
${ }^{517}$ Article 29, Sec. 1.

${ }^{518}$ Article 29, Sec. 4.

${ }^{519}$ Article 9.

${ }^{520}$ TANZ. CONST. art. 9(1)(g) (1977).
} 
guarantee might be limited. ${ }^{521}$ Furthermore, "equal opportunities" may also be narrow in its scope and can only be properly defined through adjudication. ${ }^{522}$

Beyond its own constitutional guarantees of equality, Tanzania has also undertaken commitments to protect the rights of its citizens on the world stage. On a regional level, the African Charter on Human and Peoples' Rights ("the Charter") provides for a number of civil and political rights traditionally referred to as "first generation rights." 523 The Charter provides that every person is equal under the law and is entitled to equal protection under the law. ${ }^{524}$ Article 2 further maintains that every individual shall enjoy such rights without distinction of any kind. ${ }^{525}$ As a signatory to the Charter, and having ratified it in $1984,{ }^{526}$ Tanzania is bound to provide equal protection under its laws regardless of a citizen's gender or religion.

Tanzania's membership in the United Nations also reflects its a commitment to provide equality before the law to its citizens. Although it is not a binding legal instrument in Tanzania, the United Nations Universal Declaration of Human Rights provides nations with a framework with which to address the rights of individuals. ${ }^{527}$

${ }^{521}$ Freeman, supra note 322 , at 126.

${ }^{522} \mathrm{Id}$.

${ }^{523}$ Yemi Akinseye-George, New Trends in African Human Rights Law: Prospects of an African Court of Human Rights, 10 U. MIAMI INT'L \& COMP. L. REV. 159, 161 (2001).

${ }^{524}$ Organization of African Unity: Banjul Charter on African Human and Peoples' Rights, 1982, 1 I.L.M. 58. Although sometimes described as a "meaningless document," the African Charter on Human and Peoples' Rights is the first attempt by African leaders to "establish a regional machinery for the implementation of the rights of Africans." Akinseye-George, supra note 523 at 162.

${ }^{525} \mathrm{Id}$. Article 2 provides, "Every individual shall be entitled to the enjoyment of the rights and freedoms recognized and guaranteed in the present Charter without distinction of any kind such as race, ethnic group, color, sex, language, religion, political or any other opinion, national and social origin, fortune, birth or other status."

${ }^{526}$ List of Countries Which Have Signed, Ratified/Acceded to the African Charter on Human and Peoples' Rights, available at http://www.africa union.org/root/au/Documents/Treaties/List/African\%20Charter\%20on $\% 20$ Human \%20and\%20Peoples\%20Rights.pdf.

${ }^{527}$ Article 7, Universal Declaration of Human Rights. The Declaration is based on the "inherent dignity" of all people and affirms the equal rights of all men and women. The Declaration gives, "human rights precedence over the power of the state." Although states are permitted to regulate rights, they are 
Furthermore, the LMA purports to eliminate discrimination against women in accordance with not only the Tanzanian constitution, but also the United Nations Convention on the Elimination of All Forms of Discrimination Against Women (“CEDAW"). ${ }^{528}$ CEDAW, which is the single most important international legal instrument of women's rights, established a comprehensive women's equality statement that had binding legal effects amongst countries that ratified the Convention. ${ }^{529}$

The spate of domestic and international legal instruments currently in force in Tanzania provides a broad justification for the state its jurisdiction with regard to individuals trapped in the paradox of multicultural vulnerability, either through legislative action or court intervention. Indeed, the Tanzanian judiciary has already demonstrated a willingness to invoke such authority. In the 1990 case of Ephraim v. Pastory and Anor, ${ }^{530}$ the High Court overruled a customary rule that barred women, but not men, from selling inherited clan land. ${ }^{531}$ In its reasoning, the Court relied on Article 13(4) of the Constitution, which states that "no person shall be treated in a discriminatory

prohibited from violating them. Since the Declaration is not legally binding, there are no signatories to the Declaration. Instead, the Declaration was ratified through a proclamation by the General Assembly in 1948 with a count of 48 votes to none with only 8 abstentions. See United Nations Association of Canada, available at http://www.unac.org/rights/question.html.

${ }_{528}$ Freeman, supra note 322, at 127.

${ }^{529}$ See Andrew Byrnes, The Convention on the Elimination of All Forms of Discrimination against Women, in THE HUMAN RightS OF WOMEN: INTERNATIONAL INSTRUMENTS AND AFRICAN EXPERIENCES, 119, 120 (Wolfgang Benedek et al. eds., 2002); Kaniye S. A. Ebeku, A New Dawn for African Women? Prospects of Africa's Protocol on Women's Rights, 16 Sri. Lanka J. Int'l. L. 83, 100 (2004). See Also, Fran P. Hosken, Toward a Definition of Women's Human Rights, 3 Hum. Rts. Q. 1, 6 (1981). Tanzania also ratified the following conventions related to the rights of women and children: Convention on the Rights of the Child (1991), the Civil and Political Rights Covenant (1976), the Economic, Social and Cultural Rights Covenant (1976), the Banjul Charter (1984), Beijing Declaration and its Platform for Action (1995), SADC Declaration on Gender and Development Policy (2000). Anika Rahman \& Nahid Toubia, Female Genital Mutilation, A Guide to Laws and Policies Worldwide 19, 222 (Zed Books Ltd., Center for Reproductive Law and Policy and Research Action and Information Network for the Bodily Integrity of Women, 2000).

${ }^{530}$ High Court at Mwanza, Civ. App. No. 70/89 (22 Feb. 1990), cited in Marsha A. Freeman, Women, Law, and Land at the Local Level: Claiming Women's Rights in Domestic Legal Systems, 16 HuM. RTS. Q. 559, 570 (1994).

${ }^{531}$ Freeman, supra note 530, at 570. 
manner by any person acting by virtue of any law or in the discharge of a function of any state office or the party, and its organs." ${ }^{532}$ Although the Constitution does not explicitly refer to gender in its definition of "discriminatory," the Court nevertheless interpreted Tanzania's ratification of various international human rights instruments, including CEDAW, as supporting the rights of women. ${ }^{533}$

Consequently, the Ephraim case demonstrates that such multilateral commitments can positively impact Tanzanian women by providing with viable alternatives to nomoi group jurisdiction. As Marsha Freeman observes, "[m]aking the claim possible is an investment in the future." 534

\section{Challenges and Opportunities for Reform in Tanzania}

While Shachar's model of transformative accommodation presents an insightful approach for jurists and policy-makers faced with the complexities of a pluralist society such as that of Tanzania, a program of joint governance that embodies its ideals may be limited by other practical considerations. Eric J. Mitnick, for example, points out that the competitive effect produced by the choice of jurisdictions made available to the individual under transformative accommodation also depends "not only [on] clearly delineated choice options but also the capacity to exercise such options."535 In particular, individuals who might benefit from opting out of nomoi group jurisdiction may be constrained from doing so due to the strength of the individual's attachment to the community. ${ }^{536}$ As such, "individuals socialized within a particular nomos to be

\footnotetext{
${ }^{532} I d$.

${ }^{533} \mathrm{Id}$.

${ }^{534}$ Id. at 562.

${ }_{535}$ Mitnick, supra note 24, at 1659.

${ }^{536} \mathrm{Id}$.
} 
compliant - individuals socialized into vulnerability, that is - may have a particularly difficult time suddenly exercising agency."537

Even where a woman's desire to opt-out might be more pronounced, overt community pressure or lack of resources may prevent the woman from exercising her choice options. While the partial exit provided by transformative accommodation merely serves as a fallback measure and thus should be less intrusive to community affairs, such a challenge to nomoi group authority still generates a "rights vs. community" dilemma to a certain extent. This is especially true for women with limited access to education or money, ${ }^{538}$ as " $[\mathrm{t}]$ he less financially independent women are, the more they depend on remaining in their community's good graces" and "that without the ability to support themselves independently women feel that they have no choice but to accept the 'harmful' cultural practices that their family and community encourage." ${ }^{, 59}$ Thus, in order for women to truly benefit from transformative accommodation across the board, Mitnick counsels that "a model premised on individual agency in a multicultural context must, at a minimum, provide for the sort of social, educational, and financial resources atrisk group members require to recognize, and take advantage of, jurisdictional options." 540

Indeed, examining the legal capacity of women in Tanzania is an essential step in measuring the equality afforded them under the law. ${ }^{541}$ In a general sense, legal capacity

\footnotetext{
${ }^{537} \mathrm{Id}$.

${ }^{538}$ See Susan Moller Okin, "Mistresses of Their Own Destiny”: Group Rights, Gender, and Realistic Rights of Exit, 112 ETHICS 205, 216-217 (2002).

${ }^{539}$ Hardee, supra note 143 , at 746.

${ }^{540}$ Mitnick, supra note 24, at 1660.

541 "Capacity" extends beyond the de jure or basic measure of equality. Capacity is recognized in laws in economic and legislative mandates and further it is recognized in the de facto aspect of their daily lives. Marsha A. Freeman, Measuring Equality: A Comparative Perspective on Women's Legal Capacity and
} 
refers to the ability to acknowledge and to exercise the rights and corresponding responsibilities of an adult within their society. ${ }^{542}$ Tanzanian women suffer from myriad problems in trying fulfilling their legal capacity, such as a lack of knowledge of their substantive and procedural rights, as well as difficulties in framing and expressing their claims. ${ }^{543}$ On the other hand, it is argued that in Zanzibar in particular, Muslim women are quite knowledgeable about their rights and tend to be aware of the social norms that define a divorce. ${ }^{544}$ Furthermore, they also have equal access to mediation through wazee, shehas or the kadhi's court. ${ }^{545}$ Nevertheless, awareness of legal rights is diffuse throughout Tanzania, where urban women, particularly those of greater economic means are more likely to utilize the machinery of the official courts than their rural counterparts. ${ }^{546}$ Therefore, programs to educate women on a local level are still crucial for ensuring equal access to the state justice system at all levels.

The kind of measures to which Mitnick refers bring to mind broader structural concerns that are truly global in nature, thus highlighting the importance of the work of

Constitutional Rights in Five Commonwealth Countries, 5 BERKELEY WOMEN's L. J. 110, 112-13 (19891990).

${ }^{542} I d$.

${ }^{543}$ Ulrike Wanitzek, Legally Unrepresented Women Petitioners in the Lower Court of Tanzania: A Case of Justice Denied?, 30 \&31 J. Legal PluRALISM \& UnOfFicial L. 255, 263 (1990-1991). "There was no doubt that court adjudication of these matters could aggravate tensions within communities. Just as there were advocates for change in the direction of equality for women, so were there articulate voices forecasting that integration of new norms would result in the collapse of the family, problems with a new generation of youth unfamiliar with the norms of their communities, and a descent into lawlessness." JENNIFER WIDNER, BUILDING THE RULE OF LAW 338-9 (University of Michigan, Norton \& Company, 2001).

${ }_{544}^{54}$ Stiles, “There is No Stranger to Marriage Here!”, supra note 426.

${ }^{545}$ In observing the Kadhi's Courts in Kenya, Susan Hirsch found that Swahili women, rarely criticize the Kadhi's Courts because it is a venue where women can obtain their legal rights and kadhis are seen as people who "help" when there are few other options for resolving disputes. Susan Hirsch, Kadhi's Courts as Complex Sites of Resistance: The State, Islam, and Gender in Postcolonial Kenya, in CONTESTED STATES 207, 219 (Mindie Lazarus-Black et al. eds., 1994).

${ }^{546}$ Interviews that the authors conducted at the legal aid clinic of the University of Dar es Salaam elicited such anecdotes as women walking as far as fifty kilometers to seek consultation at the clinic. Interview with Charles Majinge, Att'y, Legal Aid Clinic, Univ. of Dar es Salaam, in Dar es Salaam, Tanz. (Mar. 6, 2006). 
non-governmental organizations ("NGOs") on the ground in enabling women to know and assert their rights in Tanzania. ${ }^{547}$ For example, the United Nations Committee on the Elimination of All Forms of Discrimination against Women has reported on the efforts made by NGOs and the government to raise the awareness of women's rights through outlets such as the Legal Aid Committee of the University of Dar es Salaam and the Tanzania Media Women's Association (TAMWA), as well as various educational campaigns utilizing easy-to-read booklets, radio programs, and newspaper columns. ${ }^{548}$

Because Tanzania's commitments to protect individual rights have both international and domestic components, campaigns to strengthen the position of women in Tanzania "means creating support for the effort, through local organizations and international networks, to share both the burdens and the benefits." ${ }^{549}$ In engaging with religious tradition, Cheryl Preston observes that the success of this collaborative dynamic depends on the subtle shaping of everyday transactions:

Outsider feminists need ultimately to defer to those with the greatest stake in a religious institution for answers. At the same time, outsiders can, through questioning, help tease out whether something is going on entirely different from theology. And sometimes it helps feminists on the inside to get support from women on the outside, especially when those women carry some clout.

While dividing theology from culture may not be realistic on the large scale, it can work in individual cases and with incremental steps. Women can start in their own families and with how they teach their children: "Families and communities can bring out social change by altering their daily practices." Many times the most significant changes are

\footnotetext{
${ }^{547}$ For an overview of the impact that women's groups have made on Tanzania's political and social landscape, see Aili Mari Tripp, Rethinking Civil Society: Gender Implications in Contemporary Tanzania, in CIVIL SocIETY AND THE STATE IN AFRICA 149-68 (John W. Harbeson et al. eds., 1994).

${ }^{548}$ Committee on the Elimination of All Forms of Discrimination against Women (CEDAW), Second and third periodic reports of States parties, Republic of Tanzania 7, 8 (Sept. 30, 1996).

${ }^{549}$ Freeman, supra note X, at 560.
} 
generational. We can leave our daughters a better religious community than the one we inherited. ${ }^{550}$

Indeed, the burdens are many, and overcoming them requires perseverance by those working to transform the attitudes and practices of local communities from within.

While Tanzania has been fortunate in eluding the kinds of communal strife that have plagued its neighbors, resistance to change is palpable in many sectors. In 1998, the former chairperson of the UWT publicly questioned the practice of polygamy in Tanzania, which caused her to be branded an apostate by some Muslim leaders. ${ }^{551}$ The ensuing protests in Zanzibar, which in resulted in several casualties, prompted President Mwinyi to assure the Muslim community that "the Government ha[d] no mandate to enforce amendments of the holy scriptures like the Qur'an."552 The fact even this kind of internal debate can spark such a backlash highlights how calls for social change must be presented with good faith and credibility to the communities in question.

Nevertheless, increased awareness by women of their legal rights on paper may not translate into successful vindication of those rights in court. That is to say, the next step involves "[a]n evaluation of judicial systems entails examination of how that system deals with the rights of citizens and whether these rights are respected and guaranteed." ${ }^{, 53}$ Such an inquiry reveals how strongly the rule of law operates in that society. ${ }^{554}$ The final question then is whether an effective state judicial system exists in Tanzania that can adequately protect the individual rights of those that wish to invoke its authority.

\footnotetext{
${ }^{550}$ Preston, supra note 32, at 207 (quoting Vanaja Dhruvajaran, Religion, Spirituality, and Feminism, in GENDER, RACE, AND NATION: A GLOBAL PeRsPeCtive 299 (Vanaja Dhruvajaran \& Jill Vickers eds., 2002).

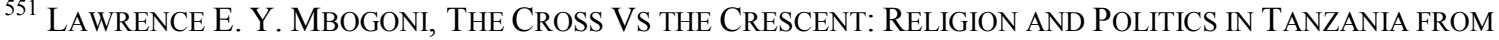
THE 1890S TO THE 1990S 167 (2005).

${ }_{552} \mathrm{Id}$.

${ }_{553}^{554}$ Bierwagen, supra note 2, at 409.

${ }^{554} \mathrm{Id}$.
} 
Rainer Bierwagen and Chris Peter examined Tanzania's court system by looking at the independence of the judiciary, the effectiveness of legal reform, and unification of the judiciary. ${ }^{555}$ In regards to the first matter, Bierwagen and Peter found that the executive branch in both Tanganyika and Zanzibar exert considerable influence and pressure on what are considered sensitive cases. ${ }^{556}$ Tanzanian judges, as high as former Chief Justices, have been blindly subservient to the political parties that appointed them. ${ }^{557}$ The executive has even jailed members of the judiciary for rulings that run contrary to the current political agenda. ${ }^{558}$ Thus, the ruling party appears to hold the judiciary in low esteem. Moreover, beyond political influence, attorneys and public officials admit that the judiciary is susceptible to bribes from the representing parties. ${ }^{559}$ With such a corrupt and politically influenced judiciary, a Tanzanian citizen's ability to exercise his or her constitutional rights is seriously limited.

With regard to legal reform, the Republic of Tanzania has a tendency to ignore, or take less seriously, legal issues. ${ }^{560}$ Also, "there is a tendency to underrate the intelligence of the population by assuming that particular issues will not be called to question." ${ }^{, 561}$ The Constitutional Court is one case in point. The fact that it has never convened in all the years of its existence reveals indicates its establishment as an empty political gesture. ${ }^{562}$ In fact, it is argued that a former president of Zanzibar was forced to resign for attempting to convene the Constitutional Court. ${ }^{563}$ Therefore, there is a significant

\footnotetext{
${ }^{555} \mathrm{Id}$. at 410 .

${ }_{557}^{556} \mathrm{Id}$.

${ }_{557}^{55} \mathrm{Id}$.

${ }_{558}^{55} \mathrm{Id}$.

${ }_{559}^{560}$ Mambo, supra note 461; Background Note, supra note 330.

${ }^{560}$ Bierwagen, supra note 2 at 410 .

${ }^{561} I d$. at 411 .

${ }^{562} \mathrm{Id}$.

${ }^{563} \mathrm{Id}$.
} 
unwillingness within the executive branch to remedy the unconstitutionality of certain laws.

Bierwagen and Peter's findings, which were published in 1989, expressed optimism that the dualistic court system of Tanzania was headed on path towards unification. ${ }^{564}$ Experienced jurists from the mainland had already been traveling to Zanzibar in order to strengthen that region's legal system. ${ }^{565}$ Bierwagen and Peter thus viewed the cementing of the two systems as a solution to increasing respect for the rule of law and heightening protection of individual rights. ${ }^{566}$ In the context of family law, the consolidation of state legal systems thus would arguably aid in the protection of individual rights by providing a unified alternative forum to the authority of accommodated nomoi groups.

\section{CONCLUSION}

For the host of young countries dotting the African continent, colonialism is not mere textbook fodder, but rather a profound historical phenomenon whose memory remains fresh, especially for those generations old enough to experience it firsthand. In the legal realm, the distinctions created by colonial administrators gave rise to a fragmented system of justice based on various ethnic, religious, and tribal categories. For newly independent colonies like Tanzania, this pluralist paradigm persisted in some areas of law, this time supported by notions of multicultural accommodation instead of colonialist desires to maintain racial separatism. Because of its role as the gatekeeper of

\footnotetext{
${ }^{564}$ Id. at 412.

${ }^{565} \mathrm{Id}$.

${ }^{566} \mathrm{Id}$.
} 
group identity, family law is a major field where community autonomy has been allowed to flourish.

As programs of multicultural accommodation have been established across a wide variety of jurisdictions, critics have now turned to unique problems faced by individuals subordinated within accommodated communities, particularly women. While most countries have adopted constitutional guarantees of equal protection and signed international conventions calling for an end to gender-based discrimination, these commitments may be severely undermined by the state's decision to let religious and customary traditions control issues like property rights and maintenance. The fact that women are disproportionately affected by poverty in many developing countries only underscores the necessity of eliminating discriminatory barriers to their increased participation in the economic life of the nation.

This recent literature on multiculturalism's impact on women has thus attempted to reconcile the tension between individual and group rights by advancing a system based on political compromise and competitive jurisdiction. Under the model of transformative accommodation, the state stands as the guarantor of equal protection by responding to women's claims for economic and social justice where these demands have been denied at the community level. Officially granting women this option, of course, is only one step - measures that promote awareness of options and a realistic ability to exercise them are essential if true legal empowerment is to flourish.

The government on the mainland of Tanzania took a bold step decades ago in enacting a uniform law of marriage. While the Law of Marriage Act of 1971 was an incomplete integration of preexisting laws of marriage and divorce, it provided certain 
entrance points for state authority to ensure greater individual rights for women. Nevertheless, flaws in the statute have been exposed over the years, and lawmakers would greatly advance the egalitarian aims of the original Act by finally enacting many of the changes proposed by the Law Reform Commission and other observers. Likewise, marriage law in Zanzibar is ripe for reassessment, as the kinds of reforms that have reduced gender-based discrimination in Tanganyika have yet to take hold in the islands.

A narrow investigation into marriage law ultimately arrives at the broader issues of access to justice and the rule of law as it operates in Tanzania. These structural problems go beyond the confines of any one area of academic inquiry and require the continued sharing of expertise on an international scope to support social and political transformations at the local level. Especially in nations where government resources are limited, the task of promoting economic and political empowerment of women and other minorities lies with private institutions and non-profit organizations. The scope of services that these agents provide was all too evident from the authors' own field study in Tanzania. It is thus the authors' hope that this article and the information it imparts serve as one point of reference the continuing global dialogue. 